\title{
A comparative morphological study of the kinorhynch genera Antygomonas and Semnoderes (Kinorhyncha: Cyclorhagida)
}

\author{
Martin V. Sørensen • Iben Heiner · Jesper G. Hansen
}

Received: 14 July 2008 / Revised: 6 October 2008 / Accepted: 7 October 2008 / Published online: 25 October 2008

(c) Springer-Verlag and AWI 2008

\begin{abstract}
Detailed information revealed through combined use of light- and scanning electron microscopy, is given for two species of kinorhynchs, representing the cyclorhagid genera Semnoderes and Antygomonas. The two species have not previously been examined using SEM, and the new observations point out several similarities between species of the two genera, which could indicate a potential close relationship. The generated data is meant to be incorporated in a future phylogenetic analysis in order to clarify the phylogenetic relationships among kinorhynchs.
\end{abstract}

Keywords Antygomonas incomitata - Introvert . Morphology $\cdot$ Scanning electron microscopy $\cdot$ Semnoderes armiger

\section{Introduction}

Kinorhynchs are microscopic, segmented, marine animals. They belong to the large ecdysozoan clade (Aguinaldo et al. 1997) and are considered sister taxon to the priapulids (Neuhaus and Higgins 2002; Dunn et al. 2008; Sørensen et al. 2008) or loriciferans (Neuhaus and Higgins 2002, however see Sørensen et al. 2008). Various taxonomic classifications for kinorhynchs exist (see Higgins 1990; Adrianov and Malakhov 1999), but their actual interrelationships have never been examined using a proper numerical phylogenetic

Communicated by P. Funch.

M. V. Sørensen $(\bowtie) \cdot$ I. Heiner · J. G. Hansen

Invertebrate Department, Zoological Museum,

The Natural History Museum of Denmark,

University of Copenhagen, Universitetsparken 15,

2100 Copenhagen, Denmark

e-mail: mvsorensen@bi.ku.dk; mvsorensen@snm.ku.dk approach. In order to gather the required data for a phylogenetic study, the detailed morphology of introvert appendages and cuticular structures on the trunk have been examined, or in some cases re-examined, in selected species of kinorhynchs using light- and scanning electron microscopy. Such studies have previously demonstrated that they can provide significant new information from otherwise well-described species (see e.g., Kristensen and Higgins 1991; Nebelsick 1992; Ga Ordóñez et al. 2000; Sørensen 2006) as well as substantially improved descriptions of new species (see e.g., Sørensen 2006, 2007, 2008; Sørensen et al. 2007; Ga Ordóñez et al. 2008). The final goal is to produce contributions that present information on morphological character traits from a representative range of kinorhynch taxa, that can be coded and then analyzed in a phylogenetic framework.

In the present study, we focus on two kinorhynch species from two potentially closely related genera. Semnoderes armiger Zelinka 1928 represents a genus of which no species previously have been subject to SEM examinations, whereas Antygomonas incomitata Nebelsick 1990 belongs to a genus with two other well-examined species (see Bauer-Nebelsick 1996; Sørensen 2007). Hence, with supplementary data from this third species, the genus Antygomonas can be considered one of the genera with most complete documentation for all known species.

\section{Materials and methods}

Specimens for the present study were obtained at two different localities: $S$. armiger was collected with a Warén dredge from two localities situated close to each other, near the Tjärnö Marine Station in Sweden: The locality "south east of Yttre Vattenholmen" (58 $\left.52^{\prime} 13^{\prime \prime} \mathrm{N} 011^{\circ} 06^{\prime} 50^{\prime \prime} \mathrm{E}\right)$ 
was located at $30-53 \mathrm{~m}$ depth. The sediment was brown mud. The second locality, "Kostergrund" $\left(58^{\circ} 52^{\prime} 16^{\prime \prime} \mathrm{N}\right.$ $011^{\circ} 04^{\prime} 59^{\prime \prime} \mathrm{E}$ ) was located at $29-36 \mathrm{~m}$ depth. Kinorhynchs were extracted using the "bubbling and blot"-method (see Higgins 1988; Sørensen and Pardos 2008). Specimens of $A$. incomitata were collected with a mini van Veen grab in $14 \mathrm{~m}$ depth at a locality south off Torro San Isidoro, near Porto Cesareo in Taranto Bay, Italy $\left(40^{\circ} 12^{\prime} 42^{\prime \prime} \mathrm{N}\right.$ $\left.017^{\circ} 54^{\prime} 55^{\prime \prime} \mathrm{E}\right)$. The sediment consisted of coarse coralline debris mixed with mud. Kinorhynchs were extracted through freshwater shocking (see Kristensen and Higgins 1984; Sørensen and Pardos 2008).

All specimens were sorted under an Olympus ZX12 dissecting microscope and fixed in $4 \%$ borax-buffered formalin. Specimens for scanning electron microscopy were dehydrated through a graded series of ethanol, transferred to acetone and critical point dried. The dried specimens were mounted on aluminum stubs, sputter coated and examined with a JEOL JSM-6335F field emission scanning electron microscope. Specimens for light microscopy were transferred to distilled water, dehydrated through a graded series of glycerin and mounted in Fluoromount $G^{\circledR}$. The mounted specimens were examined and photographed using Nomarski differential interference contrast with an Olympus BX60 microscope equipped with a ColorView I camera. Measurements were made with $\mathrm{Ce}^{\wedge}{ }^{\wedge} \mathrm{D}$ software for analysis of light microscopical photos.

Twelve specimens of each species included in the present study and mounted for light microscopy were stored in the collection of the Zoological Museum, University of Copenhagen, under accession numbers ZMUC KIN-208 to KIN-219 (S. armiger) and ZMUC KIN-220 to KIN-231 (A. incomitata). Other studied specimens are stored in the authors' personal collections.

In the following descriptions, the terminology for head, neck and trunk morphology follows Neuhaus and Higgins (2002) and Sørensen and Pardos (2008), hence, the first trunk segment is named segment 1 , followed by the second trunk segment (segment 2) and so on down to the terminal trunk segment (segment 11). Otherwise, the terminology generally follows Sørensen and Pardos (2008).

\section{Results and discussion}

Observations on external morphology in Semnoderes armiger

\section{Head}

The head consists of a mouth cone and an introvert (Figs. 1a-d, 4a). Among the inner armature of the mouth cone only the five helioscalids of ring 03 could be observed. Inner oral styles (rings 01 and 02) are present in the mouth cone as well, but their exact number and arrangement could not be examined in any of the prepared specimens. Ring 00 consists of nine outer oral styles with two segments and pointed tips (Fig. 1a). The introvert has six rings of scalids and one additional ring of trichoscalids that are associated with the placids (Fig. 2). The introvert integument between the scalids, and between placids in the neck region, is densely plicated (Fig. 1e-f). The first scalid ring (ring 01) consists of ten spinoscalids. Each spinoscalid consists of a sheath-like basis and an elongate end piece with a blunt tip. Internal septae are not evident in light microscopy (Fig. 4b), but SEM examinations show an external subdivision of the spinoscalid's end piece into a long proximal part and 5-8 short, distal pseudosegments (Figs. 1d, 5c). The end piece has a narrow fringed area on its proximal part. Otherwise, the spinoscalid is smooth. The basis is densely fringed, with a transverse row of fringes on its distal edge and a conspicuous median, longitudinal fringed area that extends over the proximal part of the end piece (Fig. 1b). Ring 02 has ten scalids located in between and slightly below the bases of the spinoscalids (Figs. 1b-d, 2). Each scalid consists of a basal fringe, a proximal serrated sheath and an end piece with small hairs and a pointed tip. The following rings carry 20 (ring 03), 5 (ring 04), 15 (ring 05), and 15 (ring 06) scalids (Fig. 2). The scalids in rings 02-05 are generally uniform in shape, whereas their lengths decrease slightly towards the most posterior rings. The scalids of ring 06 are considerably shorter than those in the more anterior rings, the basal fringes are missing and the fringes on the proximal bases and end pieces are much shorter (Fig. 1d). Fourteen trichoscalids are present in the most posterior part of the introvert (Fig. 2). They attach to the introvert directly, and not through trichoscalid plates (Fig. 1e-f). The trichoscalids are narrow and densely covered with hairs. At their bases, long hairs form a brush that extends almost over half the length of the trichoscalids (Fig. 1f). The position of each trichoscalid is correlated with a corresponding placid in the neck. However, the two placids next to the midventral one do not have any associated trichoscalids (Figs. 1f, 2).

The location of scalids in rings 1-6 follows a strict pattern around the introvert. Described section-wise, the midventral section (section 1) and all odd numbered sections possess seven scalids (Figs. 1c, 2), whereas the middorsal section (section 6) and all even numbered sections have six scalids (Figs. 1d, 2). Trichoscalids are not a part of this pattern since their positions depend on the placid sizes and locations.

Neck

The neck consists of 16 placids that are modified in correspondence with the aberrant head opening that characterizes 
Fig. 1 Scanning electron micrographs showing mouth cone and introvert details in Semnoderes armiger. a Outer oral styles. b Introvert sections 1 and 2. c Introvert section 9. d Introvert section 4. e Lateral view of partly retracted introvert showing sections 2-5. f Ventral view of partly retracted introvert showing sections 10,1 and 2 . $m v p$ midventral placid, $p l$ placid, $s c$ scalid, $s p$ spinoscalid, $t r$ trichoscalid. Digits after labels refer to mouth cone and introvert ring numbers
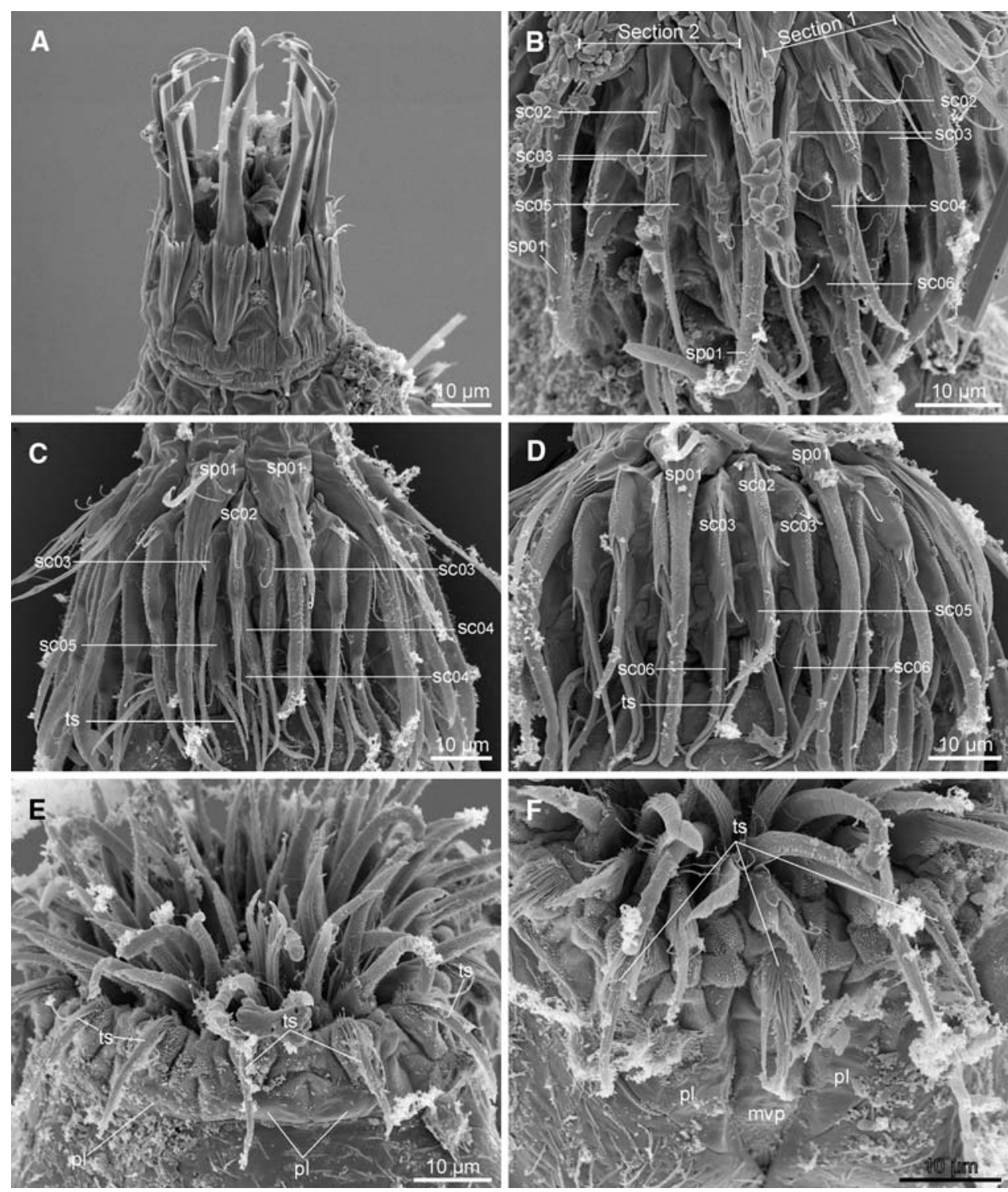

species of the genus (Figs. 1e-f, 2, 3a-b, 4b, 5a-b). The midventral and middorsal placids are located in the deep incisions of segment 1 , and are therefore narrow and elongate (Figs. 3a-b, 5a-b). Placids next to the midventral one are located on the rim of the ventral incision, have broad bases and taper towards their distal tips. Other, more lateral placids are broad and fairly low (Figs. 1e, 4b). All placids are clearly offset from segment 1 by a join, but in general the placids appear soft and flexible. The cuticle in between the placids is densely plicated.

\section{Trunk and spines}

The trunk consists of 11 segments with spines and sensory spots (Fig. 3a-b). Measurements of segments and spines are given in Table 1. A complete overview of spine and sensory spot positions is given in Table 2. Segment 1 consists of a closed ring but has deep middorsal and midventral incisions (Figs. 3a-b, 5a-b). The deep incisions enable the anterior parts of the two lateral segment halves to move towards each other when the head is retracted, hence forming a closing mechanism around the head opening. The following ten segments each consists of one tergal and two sternal plates. The trunk is conspicuously triangular in cross-section.

Middorsal acicular spines are present on segments 1-11, in a notch near the segment's posterior edge (Figs. 3b, 5a). The middorsal spines appear flexible and are densely covered with hairs. Cuspidate spines (Figs. 3a, 4c, 5e-f) are present in a lateroventral position on segments 2, 5 and 9, and in a lateral accessory position on segments 6 and 8 . The cuspidate spines consist of a swollen proximal part with scattered hairs and a narrow distal part with short scale-like hairs (Fig. 5f). Acicular spines are present in a lateroventral position on segments 

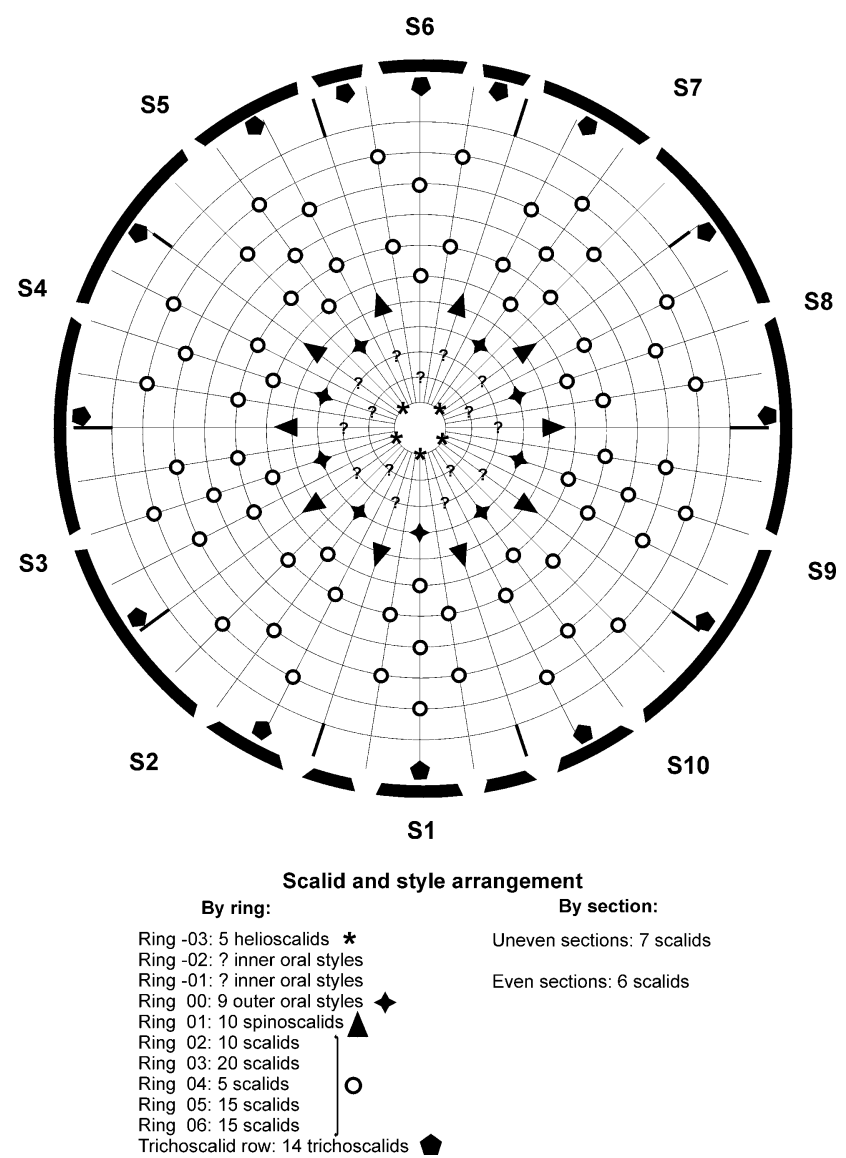

Fig. 2 Diagram of mouth cone, introvert and placids in Semnoderes armiger with indication of oral style, scalid and placid distribution. Placids are symbolized by the bent bars around the introvert diagram

$2-10$. The acicular spines on segment 2 are very short and flexible (Fig. 5f), and covered with long hairs. Acicular spines on the following segments are considerably longer and more rigid, and consist of a stout proximal part with dense hair covering, that tapers gradually towards a distal less hirsute part (Figs. 5e, 6d). The terminal segment in both sexes has lateral terminal spines, lateral terminal accessory spines and a midterminal spine (Figs. 3c, 6e-f).

\section{Sensory spots}

Pairs of paradorsal sensory spots are located close to the middorsal spines on segments 1-9 (Figs. 3b, 5a). The sensory spots are almost circular and consist of numerous minute papillae. It was not possible to determine the number of pores. A lateral series of sensory spots is present on segments 1-10 (Figs. 3a-b, 4c, 5c, e). The sensory spot on segment 1 is located in a laterodorsal position that switches to a sublateral position on segment 2 , and back to a midlateral position on segment 3 (Figs. 3a-b, 4c). No lateral sensory spots are present on segment 4 . Midlateral sensory spots are located on segments 5-8, and sublateral ones on segments

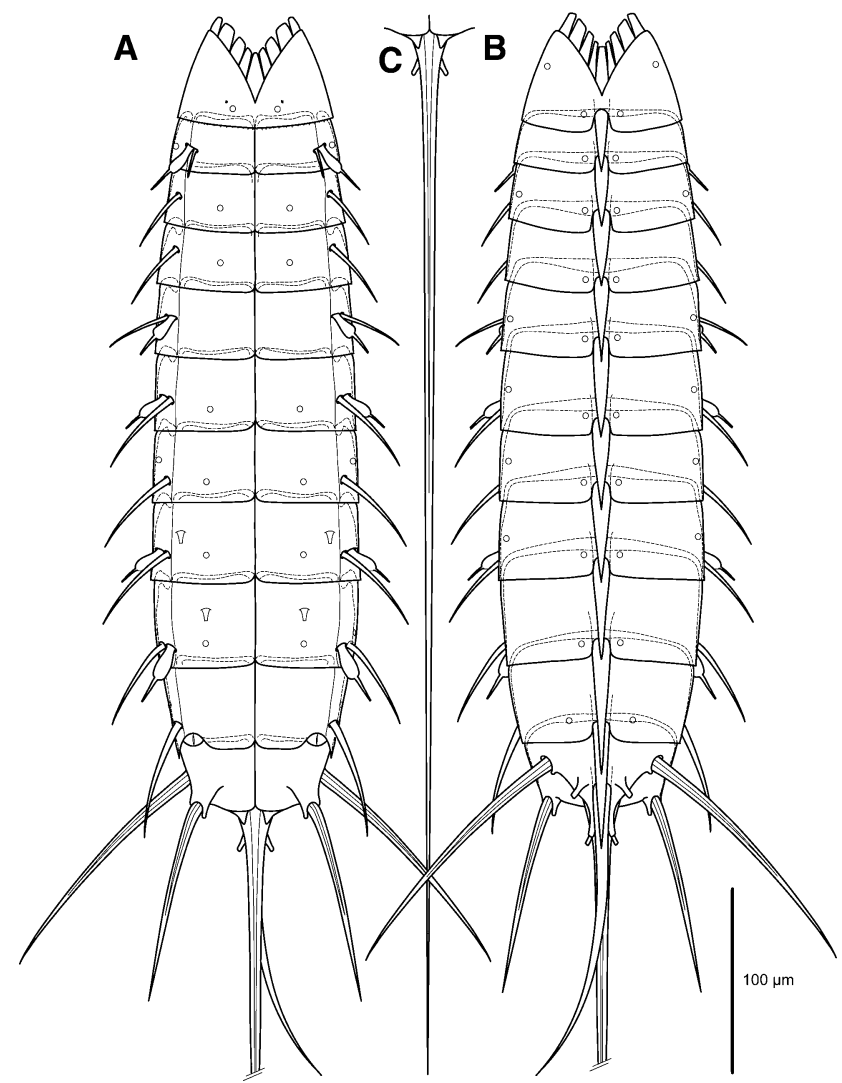

Fig. 3 Semnoderes armiger, female. a Ventral view. b Dorsal view. c Midterminal spine

7, 9 and 10. Segment 10 also has a pair of subdorsal sensory spots (Figs. 3b, 6c). Furthermore, one specimen apparently had a pair of lateral accessory sensory spots on segment 3 , but sensory spots in this position were not observed on other specimens. All sensory spots in the lateral series are either rounded or droplet-shaped, and consist of numerous minute papillae and three pores. It was difficult to clarify whether any tubes were present. Ventromedial sensory spots are present on segments 1, 3-4 and 6-9 (Fig. 3a). The sensory spots on segment 1 have two pores, one regular one and one on the tip of a tube, and belong to type 2 sensu Nebelsick 1992 (Fig. 5d). Other ventromedial sensory spots are rounded and resemble those in the lateral series. The terminal segment has three pairs of modified sensory spots (type 3 sensory spots sensu Nebelsick 1992). Two pairs of modified sensory spots are present in a subdorsal position, with one pair close to the middorsal spine and one pair at the base of the midterminal spine (Fig. 6e). A pair of modified sensory spots is furthermore located more ventrally at the bases of the lateral terminal spines (Fig. 6f).

\section{Glandular cell outlets}

It was not possible to identify any glandular cells using light microscopy, and with SEM only one pair of type 1 
Fig. 4 Light microscope photos of Semnoderes armiger. a Introvert and mouth cone, lateral view. b Introvert and segment 1 , lateral view. c Segments 1-5, lateral view. d Detail of lateroventral and ventrolateral positions on segments 8 and 9. lvac lateroventral acicular spine, $l v c u$ lateroventral cuspidate spine, oos outer oral styles, $p a$ papilla, $p l$ placid, $s p$ spinoscalid, $t r$ trichoscalid. Arrows mark positions of sensory spots
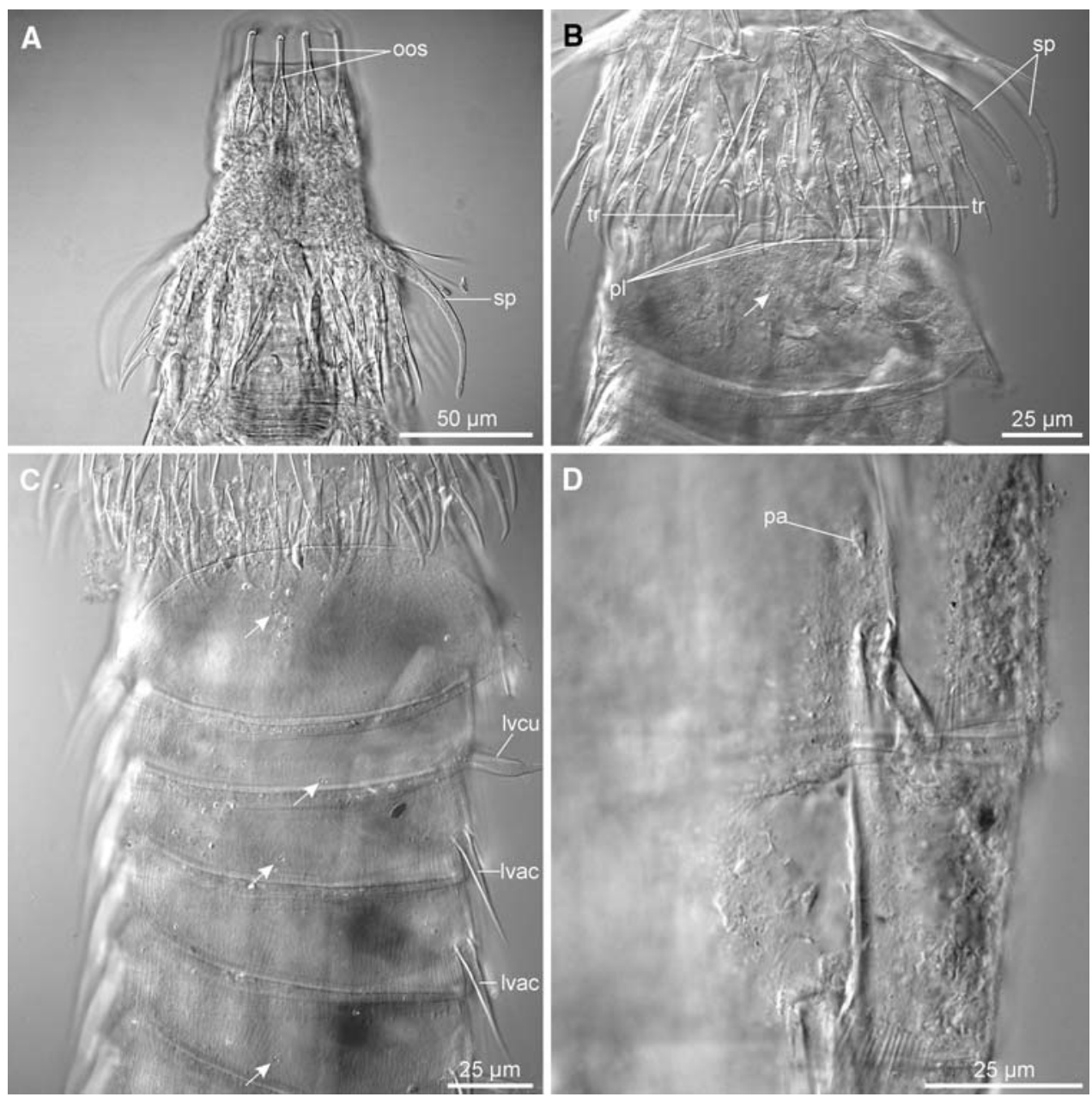

outlets was identified. This pair is located in a ventromedial position on segment 1 .

\section{Papillae}

Pairs of single papillae were observed in female specimens only. The papillae are minute cuticular structures (ca. 1.5$2.0 \mu \mathrm{m}$ ), consisting of a fringed basal collar, and a conical end piece with a terminal pore (Fig. 6b). Despite their minute size, they can be identified with SEM (Fig. 6b) as well as LM (Fig. 4d). Papillae are found in a ventrolateral position on segment 8 (Figs. 3a, 6d) and in a ventromedial position on segment 9 (Figs. 3a, 6a).

\section{Other cuticular structures}

Segment 1 is covered with relatively long, thin cuticular hairs that emerge through rounded perforation sites (Fig. 5a-c). The covering gets denser in an elongate area anterior to the middorsal spine (Fig. 5a). On the following ten segments, the hairs are scale-like and much shorter, and they do not emerge through perforations (Figs. 5e-f, 6). Internal muscle attachment sites are marked with less hirsute areas in sublateral and ventrolateral positions. Areas with densely set longer hairs are present anterior to the middorsal and lateroventral spines. The posterior segment margins are serrated, but an actual pectinate fringe is not present. Patterns in the scale-like hairs mark two somewhat indistinct secondary fringes, anteriorly on the tergal plates. A much more distinct secondary fringe is present near the anterior margin of the sternal plates. This fringe consists of a straight folding equipped with one row of short pointed hairs (Fig. 5f). It was not possible to locate the protonephridial sieve plate, but a very small sublateral opening on segment 9 could indicate the presence of the nephridiopore.

Outer primary sexual characters are present in females only. A pair of ventrolateral gonopores is present in the intersegmental zone between segments 10 and 11, and the posterior margins of the sternal plates in segment 10 are slightly incised in the same position (Fig. 6f). Females are furthermore distinguished by the presence of ventrolateral papillae on segment 8 and ventromedial ones on segment 9 . 
Fig. 5 Scanning electron micrographs showing trunk morphology and cuticular details in Semnoderes armiger. a Segment 1, dorsal view. b Segment 1, ventral view. c Segment 1, lateral view. d Close-up showing ventromedial type 2 sensory spot on segment 1. e Segments 4-5, lateral view. f Segments 1-3, ventral view. ldss laterodorsal sensory spot, lvac lateroventral acicular spine, lvcu lateroventral cuspidate spine, $m d$ middorsal spine, $m d p$ middorsal placid, $m l s s$ midlateral sensory spot, $m v p$ midventral placid, $p d s s$ paradorsal sensory spot, $p l$ placid, $s p$ spinoscalid, $s p f$ secondary pectinate fringe, $t u$ tube, $v m s s$ ventromedial sensory spot
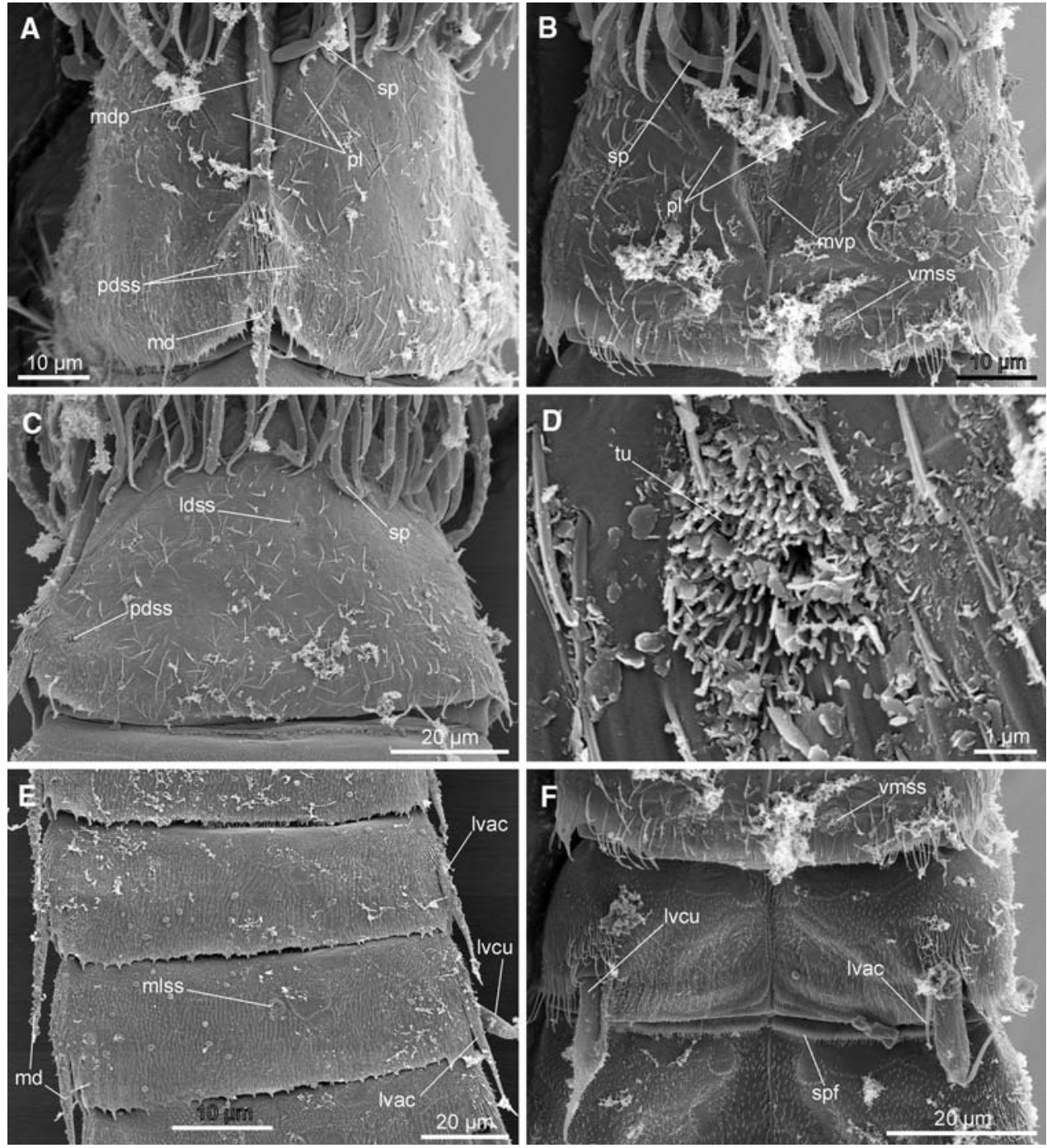

Comparison with previous observations

Three species currently constitutes the genus Semnoderes: S. armiger Zelinka 1928, S. ponticus Băcescu and Băcescu 1956, and S. pacificus Higgins 1967. These are most easily distinguished by their spine patterns, in particular the position of lateral accessory cuspidate spines. S. pacificus was described from New Caledonia in the South West Pacific, but had also been recorded from the Californian Coast (Higgins 1967). More recently Sørensen (2006) recorded a single specimen of Semnoderes in coral detritus collected at Bocas del Toro near the Atlantic Coast of Panama. Even though spine lengths and dimensions differed considerably, the recorded specimen was tentatively identified as cf. $S$. pacificus based on its spine pattern. S. ponticus is known from the Black Sea only (Băcescu and Băcescu 1956; Băcescu 1968).

Semnoderes armiger is the most frequently recorded species of the genus and its known distribution includes the
Black Sea, the Mediterranean Sea, and the West European Coast, including Great Britain and the Faroe Islands (Zelinka 1928; McIntyre 1962; Nyholm 1947; Sheremetevskij 1974; Sørensen and Pardos 2008). The specimens examined in the present study were collected near Tjärnö at the Swedish West Coast, relatively close to the locality where $S$. armiger previously was recorded by Nyholm (1947).

Comparison with the morphometric data of the type material from the Adriatic Sea (see Zelinka 1928) shows that the Swedish specimens (Table 1) examined in the present study are slightly larger. The segments in the Swedish specimens are either equal in length or up to $20 \%$ longer than those in the type specimens. Also the average trunk length of the Swedish specimens is $20 \%$ larger than that in the type specimens. However, the trunk length of the smallest recorded Swedish specimen $(372 \mu \mathrm{m})$ is fairly close to the length of the type specimens $(350 \mu \mathrm{m})$, and in general we find that the recorded size differences can be neglected. 
Table 1 Measurements of adult Semnoderes armiger from Tjärnö, Sweden, including number of measured specimens $(n)$ and standard deviation (SD)

\begin{tabular}{|c|c|c|c|c|}
\hline Character & $n$ & Range & Mean $(\mu \mathrm{m})$ & $\mathrm{SD}(\mu \mathrm{m})$ \\
\hline TL & 12 & $372-500 \mu \mathrm{m}$ & 418 & 34.38 \\
\hline MSW-5 & 1 & $56 \mu \mathrm{m}$ & - & - \\
\hline MSW-5/TL & 1 & $11.2 \%$ & - & - \\
\hline SW-10 & 1 & $44 \mu \mathrm{m}$ & - & - \\
\hline SW-10/TL & 1 & $8.8 \%$ & - & - \\
\hline $\mathrm{S} 1$ & 12 & $41-54 \mu \mathrm{m}$ & 48 & 4.06 \\
\hline S2 & 12 & $20-33 \mu \mathrm{m}$ & 27 & 4.62 \\
\hline S3 & 12 & $25-38 \mu \mathrm{m}$ & 33 & 4.00 \\
\hline S4 & 12 & $30-40 \mu \mathrm{m}$ & 36 & 3.51 \\
\hline S5 & 12 & $31-45 \mu \mathrm{m}$ & 38 & 3.78 \\
\hline S6 & 12 & $32-46 \mu \mathrm{m}$ & 42 & 4.17 \\
\hline S7 & 12 & $38-50 \mu \mathrm{m}$ & 44 & 3.61 \\
\hline S8 & 12 & $39-56 \mu \mathrm{m}$ & 48 & 5.21 \\
\hline S9 & 12 & $42-58 \mu \mathrm{m}$ & 50 & 4.74 \\
\hline S10 & 11 & $43-51 \mu \mathrm{m}$ & 47 & 2.81 \\
\hline S11 & 10 & $35-41 \mu \mathrm{m}$ & 37 & 1.96 \\
\hline MD 1 & 11 & $30-40 \mu \mathrm{m}$ & 34 & 3.29 \\
\hline MD 2 & 12 & $32-43 \mu \mathrm{m}$ & 37 & 3.08 \\
\hline MD 3 & 12 & $37-49 \mu \mathrm{m}$ & 41 & 3.48 \\
\hline MD 4 & 12 & $40-51 \mu \mathrm{m}$ & 44 & 4.27 \\
\hline MD 5 & 11 & $41-54 \mu \mathrm{m}$ & 48 & 4.43 \\
\hline MD 6 & 12 & $41-56 \mu \mathrm{m}$ & 49 & 4.75 \\
\hline MD 7 & 12 & $48-61 \mu \mathrm{m}$ & 54 & 3.87 \\
\hline MD 8 & 12 & $49-62 \mu \mathrm{m}$ & 57 & 3.83 \\
\hline MD 9 & 11 & $56-77 \mu \mathrm{m}$ & 67 & 6.47 \\
\hline MD 10 & 9 & $59-80 \mu \mathrm{m}$ & 70 & 6.48 \\
\hline MD 11 & 12 & $133-199 \mu \mathrm{m}$ & 168 & 19.35 \\
\hline LV 2 (cu) & 12 & $20-31 \mu \mathrm{m}$ & 25 & 3.37 \\
\hline LV 2 (ac) & 5 & $11-13 \mu \mathrm{m}$ & 12 & 0.71 \\
\hline LV 3 (ac) & 12 & $30-41 \mu \mathrm{m}$ & 36 & 3.33 \\
\hline LV 4 (ac) & 9 & $31-47 \mu \mathrm{m}$ & 39 & 5.63 \\
\hline LV 5 (cu) & 12 & $21-30 \mu \mathrm{m}$ & 28 & 2.71 \\
\hline LV 5 (ac) & 12 & $39-47 \mu \mathrm{m}$ & 44 & 2.71 \\
\hline LA 6 (cu) & 12 & $23-33 \mu \mathrm{m}$ & 28 & 2.78 \\
\hline LV 6 (ac) & 12 & $36-54 \mu \mathrm{m}$ & 48 & 5.28 \\
\hline LV 7 (ac) & 11 & $40-57 \mu \mathrm{m}$ & 51 & 5.03 \\
\hline LA 8 (cu) & 12 & $22-34 \mu \mathrm{m}$ & 28 & 3.58 \\
\hline LV 8 (ac) & 12 & $46-56 \mu \mathrm{m}$ & 50 & 3.26 \\
\hline LV 9 (cu) & 11 & $24-37 \mu \mathrm{m}$ & 31 & 4.21 \\
\hline LV 9 (ac) & 11 & $49-61 \mu \mathrm{m}$ & 54 & 3.56 \\
\hline LV 10 (ac) & 12 & $45-72 \mu \mathrm{m}$ & 57 & 7.94 \\
\hline LTS & 12 & $73-103 \mu \mathrm{m}$ & 88 & 9.63 \\
\hline LTAS & 12 & $121-153 \mu \mathrm{m}$ & 134 & 10.48 \\
\hline MTS & 12 & $466-644 \mu \mathrm{m}$ & 568 & 63.82 \\
\hline
\end{tabular}

$a c$ acicular spine, $c u$ cuspidate spine, $L A$ lateral accessory, $L T A S$ lateral terminal accessory spine, $L T S$ lateral terminal spine, $L V$ lateroventral, $M D$ middorsal, $M S W-5$ maximum sternal width (on segment 5), MTS midterminal spine, $S$ segment lengths, $S W$ - 10 standard width (on segment 10), $T L$ trunk length
All spine lengths in the type specimens are within the ranges of spine lengths in the Swedish population.

\section{Head appendages and their arrangement}

Zelinka (1928) does not describe the exact arrangement of the scalids on the introvert, but he notes that typical trichoscalids apparently are missing. Our observations confirm that typical shaggy trichoscalids as found, e.g., in species of Echinoderes are missing in S. armiger. However, both SEM (Fig. 1e-f) and LM (Fig. 4b) observations confirm that more narrow and elongate trichoscalids truly are present in this species.

Higgins (1967) notes that the spinoscalids in S. pacificus are characterized by having distal constrictions, forming seven short pseudosegments. According to Zelinka (1928), $S$. armiger does not have such subdivisions of the spinoscalids, and our observations partly confirm this. With LM, any constriction can hardly be recognized, but SEM observations show at least a partial subdivision. However, the constrictions are not complete all around the spinoscalid, but seem to be restricted to transverse wrinkles on the parts of the spinoscalid's surface that face the introvert. Hence, the differences between $S$. pacificus and S. armiger may very well be species diagnostic, but the character should probably be used with some caution.

The arrangement of the mouth cone and introvert armature, i.e., oral styles and scalids, may be a source of significant phylogenetic and systematic information. Even though some older reports based on LM exist, we prefer to compare with data revealed through SEM only, as the exact position of, e.g., scalids hardly can be resolved with LM. Fortunately, the amount of such data from SEM studies has increased over the last years and has become available from an increasing amount of species (see e.g., Brown 1989; Higgins 1990; Neuhaus 1993; Nebelsick 1993; BauerNebelsick 1995, 1996; Ziemer 2001; Sørensen 2007, 2008; Sørensen et al. 2007; Sørensen and Pardos 2008). A comparison of scalid arrangements across species or genera can either be done ring-wise or section-wise, and as pointed in several studies (see e.g., Higgins 1990; Sørensen 2007; Sørensen and Pardos 2008) the section-wise comparison often provides the best comparative approach.

In $S$. armiger odd numbered sections carry seven scalids distributed on rings 02-06. The anteriormost ring (ring 02) carries one scalid, the following ring two scalids, then one, two, and one scalid in the following three rings (Fig. 2). Hence, the scalid arrangement can be described as a quincunx (rings 3-5) in between a single scalid in the anterior (ring 02) and posterior (ring 06) ring. The scalid arrangement in even numbered rings differs slightly by showing one scalid in the anteriormost ring (ring 02) followed by rings with alternatingly two, one and two scalids (Fig. 2). 
Table 2 Summary of nature and location of sensory spots, glandular cells, spines and papiallae arranged by series in Semnoderes armiger from Tjärnö, Sweden

\begin{tabular}{|c|c|c|c|c|c|c|c|c|c|c|}
\hline Position segment & MD & PD & SD & LD & ML & SL & LA & LV & VL & VM \\
\hline 1 & ac & ss & & ss & & & & & & $\mathrm{ss} 2, \mathrm{gc} 1$ \\
\hline 2 & ac & ss & & & & ss & & $\mathrm{cu}, \mathrm{ac}$ & & \\
\hline 3 & ac & ss & & & ss & & ss (!) & $\mathrm{ac}$ & & ss \\
\hline 4 & ac & ss & & & & & & $\mathrm{ac}$ & & ss \\
\hline 5 & $\mathrm{ac}$ & ss & & & ss & & & $\mathrm{ac}, \mathrm{cu}$ & & \\
\hline 6 & ac & ss & & & ss & & $\mathrm{cu}$ & $\mathrm{ac}$ & & ss \\
\hline 7 & ac & ss & & & ss & ss & & ac & & ss \\
\hline 8 & ac & ss & & & ss & & $\mathrm{cu}$ & ac & $\mathrm{pa}(\mathrm{f})$ & ss \\
\hline 9 & $\mathrm{ac}$ & ss & & & & ss & & $\mathrm{ac}, \mathrm{cu}$ & & ss, pa (f) \\
\hline 10 & ac & & ss & & & ss & & ac & & \\
\hline 11 & $\mathrm{ac}, \mathrm{mts}$ & & ss 3, ss 3 & & & & ltas & lts, ss3 & & \\
\hline
\end{tabular}

$L A$ lateral accessory, $L D$ laterodorsal, $L V$ lateroventral, $M D$ middorsal, $M L$ midlateral, $P D$ paradorsal, $S D$ subdorsal, $S L$ sublateral, $V L$ ventrolateral, $V M$ ventromedial, ! indicates that the character was found in a single specimen only; $a c$ acicular spine, $c u$ cuspidate spine, $f$ female condition of sexually dimorphic character, $g c l$ type 1 glandular cell outlet, ltas lateral terminal accessory spine, lts lateral terminal spine, $m t s$ midterminal spine, $p a$ papilla, $s s 2 / 3$ sensory spot type 2/3 (in most instances it was not possible to determine the type of the sensory spot)

Fig. 6 Scanning electron micrographs showing trunk morphology and cuticular details in Semnoderes armiger. a Sternal plates in segment 9 of female specimen. b Detail showing ventromedial papilla on sternal plate of segment 10 in female specimen. c Segment 10, lateral view. d Left sternal plate of segment 8 in female specimen. e Segment 11, lateral view. f Segment 11 of female specimen, ventral view. ldss laterodorsal sensory spot, ltas lateral terminal accessory spine, lts lateral terminal spine, lvac lateroventral acicular spine, $l v c u$ lateroventral cuspidate spine, $m d$ middorsal spine, modss modified sensory spot, $m t s$ midterminal spine, $p a$ papilla, $s d s s$ subdorsal spine, $s l$ sublateral spine, vmss ventromedial sensory spot
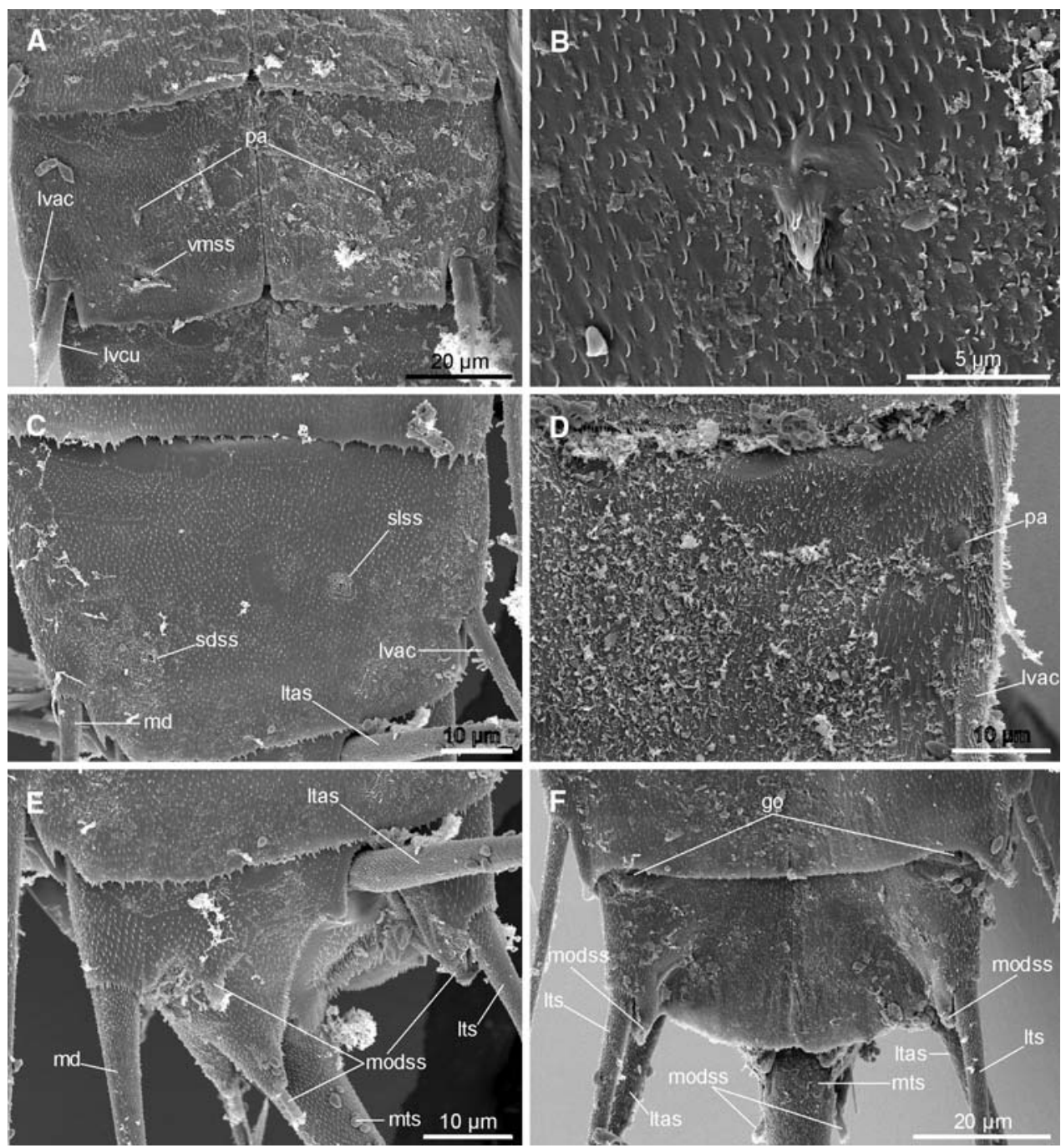
Apparently, ring 04 carries no scalids in even numbered sections, but in the following comparison we will focus on the section-wise arrangement only, and disregard the exact ring-wise position. Hence, the scalid arrangement in even numbered sections can in other words be described as a single anteriormost scalid in ring 02 , followed by a quincunx.

This section-wise arrangement is present in several other species, including: Dracoderes sp. (Sørensen, unpublished observation), Paracentrophyes praedictus (see Neuhaus 1993), Kinorhynchus phyllotropis (see Brown 1989), P. quadridentatus (Sørensen, unpublished observation), Tubulideres paulae (see Sørensen et al. 2007), Campyloderes cf. macquariae (Sørensen unpublished observation), Antygomonas oreas (see Bauer-Nebelsick 1996), A. paulae (see Sørensen 2007) and A. incomitata (present contribution). The odd numbered sections are perfectly identical among all these species, namely showing an anteriormost and a posteriormost scalid with five scalids arranged as a quincunx in between (Fig. 2). Even numbered sections show an anteriormost scalid followed by five scalids arranged as a quincunx, but slight variations of positions along the longitudinal axis occur between the species.

In $S$. armiger ring 04 has no scalids in the even numbered sections, which is identical with the condition found in Antygomonas paulae (see Sørensen 2007). Other species of Antygomonas have ring 03 devoid of scalids, leaving a small gap between the anteriormost scalid and the quincunx (see Bauer-Nebelsick 1996 and below). In general, the introvert armature in S. armiger and species of Antygomonas appears to share many similarities regarding scalid arrangement as well as morphology. In all species, the spinoscalids have conspicuously long longitudinal fringes on the basal sheath and distal pseudosegmentation. Furthermore, the medially serrated sheaths of the scalids in the following rows appear very similar.

\section{Sensory spots, glandular cells and papillae}

The distribution and morphology of sensory spots have not previously been described from any species of Semnoderes. The presence of paradorsal sensory spots flanking the middorsal spines is known from a broad range of cyclorhagid kinorhynchs, including species of Antygomonas (see BauerNebelsick 1996; Sørensen 2007), Campyloderes (see Neuhaus 2004), Condyloderes (see Adrianov et al. 2002), Dracoderes (Sørensen, personal observation), Tubulideres and Zelinkaderes (for both see Sørensen et al. 2007), and even some species of some echinoderid genera, including Fissuroderes (see Neuhaus and Blasche 2006), Cephalorhyncha (see Neuhaus and Blasche 2006; Sørensen 2008) and Echinoderes (see e.g., Sørensen 2006), but not in Polacanthoderes (see Sørensen 2008). Series of lateral and ventromedial sensory spots are common in many genera as well (see e.g., Higgins 1990; Bauer-Nebelsick 1995; Sørensen 2007; Sørensen et al. 2007 and present contribution), and the appearance and location of these sensory spots certainly represent information of phylogenetic significance but also some homoplasy. Because these sensory spots seem to represent a mix of conserved and highly variable characters, information from a more complete set of taxa is required to establish the ground patterns for each genus and subsequently facilitate a comparison at higher taxonomic levels.

As stated above, it was only possible to identify one pair of glandular cells. However, it is unlikely that no further glandular cells are present, and the difficulties observing them are probably due to the mostly lateral orientated specimens for light microscopy and the dirt covering on many SEM specimens. Using SEM for identification of the small porous fields that indicate the presence of type 1 glandular cell outlets (for definition see Sørensen and Pardos 2008) requires very clean specimens. However, we feel confident that the larger type 2 glandular cell outlets would have been identifiable, hence we can conclude that such outlets are not present in S. armiger.

The papillae observed in females in a ventrolateral position on segment 8 and ventromedial on segment 9 have not been reported previously, and similar structures are only known from species of Campyloderes (Sørensen, personal observation). It remains uncertain whether the papillae found in S. armiger and cf. C. macquariae represent homologous structures but their overall appearance and their apparent dependence on the gender could indicate a homology. However, data from more closely related species would be required and an assumed homology should be tested in a formal phylogenetic analysis.

\section{Trunk morphology and spine pattern}

The most conspicuous autapomorphy for Semnoderes is the characteristic morphology of segment 1 . In previous contributions the segment has been described as consisting of two lateral plates with middorsal and midventral joints (Zelinka 1928; Higgins 1967; Adrianov and Malakhov 1999). However, the observations from the present study clearly show that the segment consists of a single closed ring, but with deep wedge-shaped middorsal and midventral incisions in the anterior margin that give it the previously reported clamshell-like appearance (Figs. 3a-b, 5a-b).

Whereas most other kinorhynch species have a fairly straight anterior margin on segment 1 , species of Sphenoderes and Antygomonas also show modifications in this trunk region. In Sphenoderes indicus Higgins 1969 segment 1 has deep incisions in the anterior margin as well and when the head is retracted the whole segment gets modified to act as a closing mechanism in the same way as in species of Semnoderes (see Higgins 1969). The incisions in the anterior 
segment margin in species of Antygomonas are less conspicuous and do not enable the segment to contract laterally when the head retracts. However, it is still likely that this modification of the segment is part of the same transformation series that are observed in species of Semnoderes and Sphenoderes.

The presence of middorsal acicular spines on all segments are shared with species of Sphenoderes, Antygomonas, Tubulideres, Condyloderes, Centroderes and males of Campyloderes (see e.g., Zelinka 1928; Higgins 1969; Nebelsick 1990; Bauer-Nebelsick 1996; Adrianov et al. 2002; Neuhaus 2004; Sørensen 2007; Sørensen et al. 2007). Among these, the presence of cuspidate spines is shared with species of the genera Antygomonas and Condyloderes only. Cuspidate spines are furthermore present in species of Zelinkaderes (Higgins 1990, Bauer-Nebelsick 1995; Sørensen et al. 2007). It is yet too premature to be conclusive about the evolution of spine patterns and potential homologies in spine compositions among cyclorhagids. However, attention should be drawn to the conspicuous similarities between the spine compositions of segment 2 in species of Semnoderes and Antygomonas. In species of both genera there is a pair of lateroventral cuspidate spines, situated very close to a pair of short flexible acicular spines (Figs. 5f, 10c). This unusual combination of spines could indicate a closer relationship between the two genera and should be explored in more detail in future studies.

Observations on external morphology in Antygomonas incomitata

\section{Head}

The head consists of a mouth cone and an introvert (Fig. 7). The inner armature consists of five helioscalids of ring 03 , five inner oral styles of ring 02 , and 10 inner oral styles of ring 01 (Fig. 8). The helioscalids consist of two segments,
Fig. 7 Scanning electron micrographs showing mouth cone and introvert details in $A n$ tygomonas incomitata. a Outer oral styles and mouth cone with internal parts extruded, showing the inner oral styles. b Inner oral styles protruding through mouth opening. $\mathbf{c}$ Bases of outer oral styles. d Regular and interstitial placids in neck. e Introvert sections 8-10. f Middorsal placid and tips of spinoscalids. he helioscalids, io inner oral styles, ip interstitial placid, $m c$ mouth cone, $m d p$ middorsal placid, $o o$ outer oral styles, $s c$ scalid, $s p$ spinoscalid, $t r$ trichoscalid. Digits after labels refer to mouth cone and introvert ring numbers
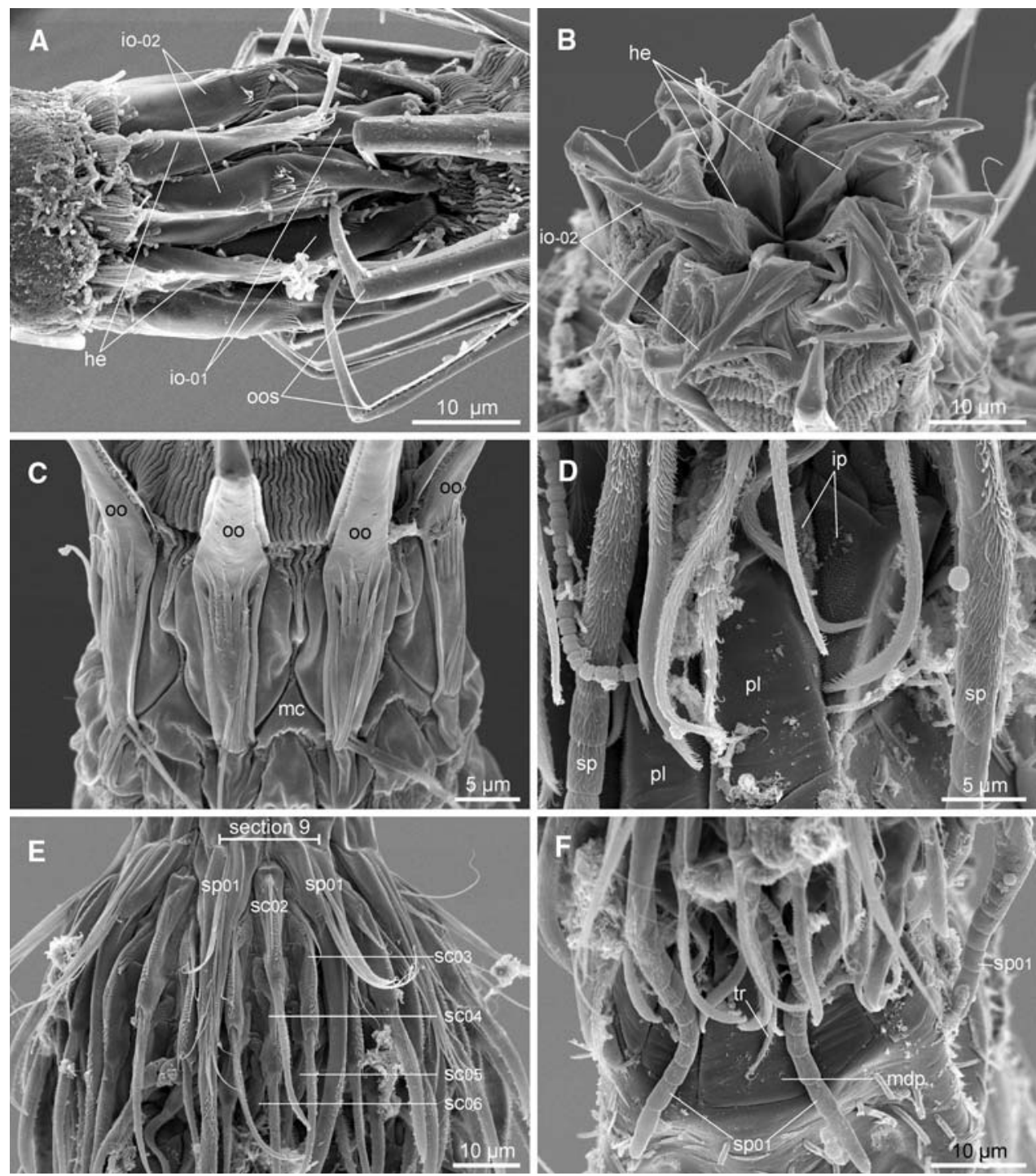

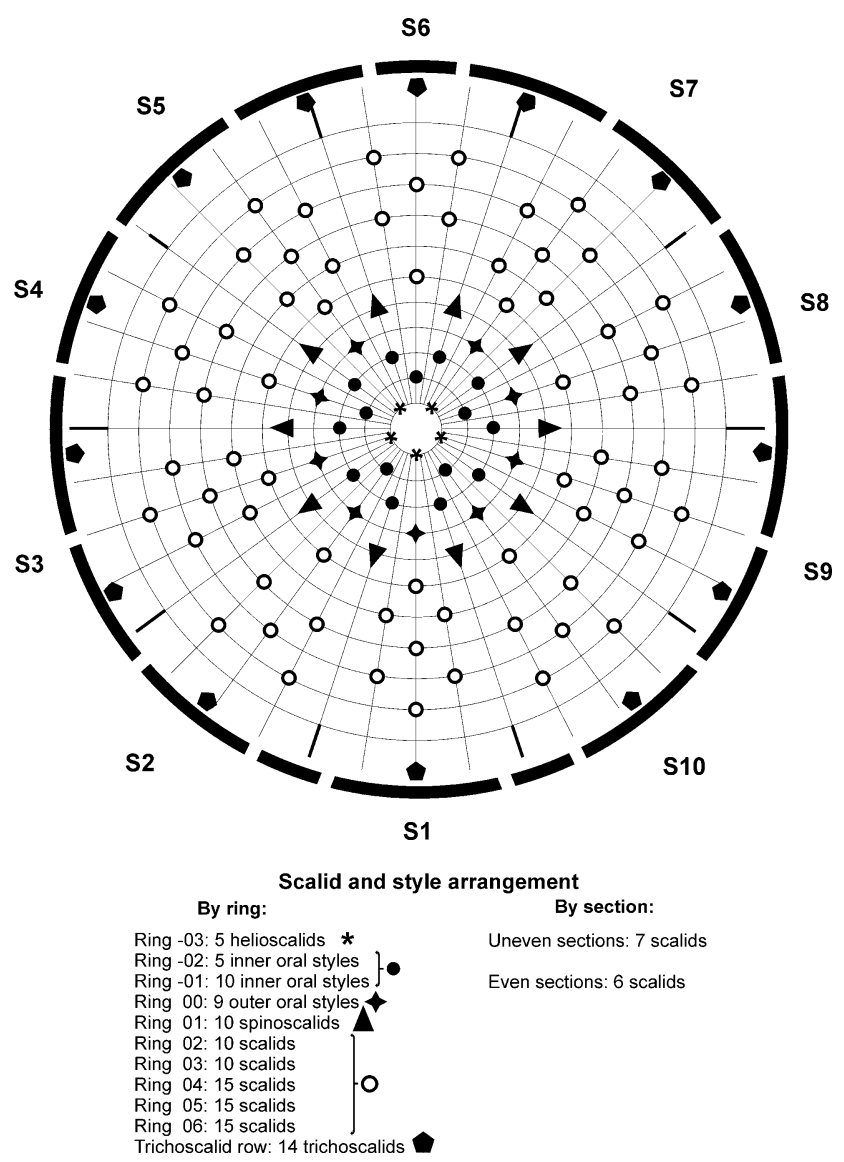

Fig. 8 Diagram of mouth cone, introvert and placids in Antygomonas incomitata with indication of oral style, scalid and placid distribution. Placids are symbolized by the bent bars around the introvert diagram

of which most of the proximal segment is covered by a fringed sheath (Fig. 7a-b). Ring 02 inner oral styles have very broad and fringed bases and a stout hook-shaped distal tip, and inner oral styles in ring 01 are only slightly smaller, but otherwise with a similar appearance (Fig. 7a). Ring 00 consists of nine outer oral styles with two segments and pointed tips. The basal part of each outer oral style is covered by a well-defined fringe with four to five tips. This fringe is covered by one additional fringe made up by six to eight slender, spinous appendages (Fig. 7c).

The introvert has six rings of scalids and one additional ring of trichoscalids that are associated with the placids (Fig. 8). The introvert integument between the scalids, and between placids in the neck region (Fig. 7d), is densely plicated. The first scalid ring (ring 01) consists of ten spinoscalids. Each spinoscalid consists of a sheath-like basis and an elongate end piece with a blunt tip. The basis has a conspicuous median, longitudinal fringed area that extends over the proximal part of the end piece, and a few lateral fringed hairs at its distal end (Fig. 7e). Otherwise, there are no fringes or hairs on the basis. The elongate end piece has a median, longitudinal row of short hairs (Fig. 7d), and consists of an undivided proximal part and a distal part with six to eight pseudosegments that are easily visualized with SEM (Fig. 7d, e) as well as LM (Fig. 9a). Ring 02 has ten scalids located in between and slightly below the bases of the spinoscalids (Figs. 7e, 8). Each scalid consists of a proximal sheath with a long, median basal hair and two lateral distal hairs, and end piece with a pointed tip. The end piece is covered with minute hairs. The following rings carry 10 (ring 03), 15 (ring 04), 15 (ring 05), and 15 (ring 06) scalids (Fig. 8). The scalids in rings $02-06$ are generally uniform in shape, whereas their lengths decrease slightly towards the most posterior rings. Fourteen trichoscalids are present in the most posterior part of the introvert (Fig. 8). They attach directly on the introvert, and not through trichoscalid plates. The trichoscalids are narrow and densely covered with short hairs (Fig. 7f). The position of each trichoscalid is correlated with a corresponding placid in the neck. However, the two placids next to the midventral one do not have any associated trichoscalids.

The location of scalids in rings 1-6 follows a strict pattern around the introvert. Described section-wise, the midventral section (section 1) and all odd numbered section possess seven scalids, whereas the middorsal section (section 6) and all even numbered sections have six scalids (Fig. 8).

Neck

The neck consists of 14 placids that are clearly separated from segment 1 through an articulation (Fig. 7f). The midventral placid is broadest (ca. $17 \mu \mathrm{m}$ at base), whereas the placids next to the midventral one are the narrowest (ca. $8 \mu \mathrm{m}$ at bases). Remaining placids are similar in size (ca. $10 \mu \mathrm{m}$ at bases). In between each placid the cuticle is stiff and folds inward, giving the impression of a double set of interstitial placids (Fig. 7d).

\section{Trunk and spines}

The trunk consists of 11 segments with spines and sensory spots. Measurements of segments and spines are given in Table 3, whereas a complete overview of spine and sensory spot positions is given in Table 4. Segment 1 consists of a closed ring, whereas the following ten segments each consist of one tergal and two sternal plates (Fig. 9c). The tergosternal junctions are very indistinct and feebly visible in several specimens. The trunk appears triangular in crosssection.

The anterior edge of segment 1 has distinct middorsal and midventral indentations (Figs. 9a, 10b). Its posterior margin has small notches where the middorsal spine and paradorsal sensory spots emerge. Otherwise the dorsal and lateral parts of the margin are straight and without indication 
Fig. 9 Light microscope photos of Antygomonas incomitata. a Introvert, dorsal view. b Left sternal plate on segment 8. c Segments 9-10 in female, ventral view. d Segments 10-11 in male, ventral view. Note the missing gonopores. e Segments 10-11 in female, dorsal view. f Segments 10-11 in female, ventral view. $f r$ fringe, $f s p$ fringes from spinoscalid bases, lacu lateral accessory cuspidate spine, ld laterodorsal spine, ltas lateral terminal accessory spine, lts lateral terminal spine, lvcu lateroventral cuspidate spine, $m d$ middorsal spine, $m t s$ midterminal spines, $s$ segment, $s p$ spinoscalid, ss sensory spot, $s t$ sternal plate, $t j$ tergosternal junction, te tergal plate, $t r$ trichoscalid. Digits after labels refer to segment numbers
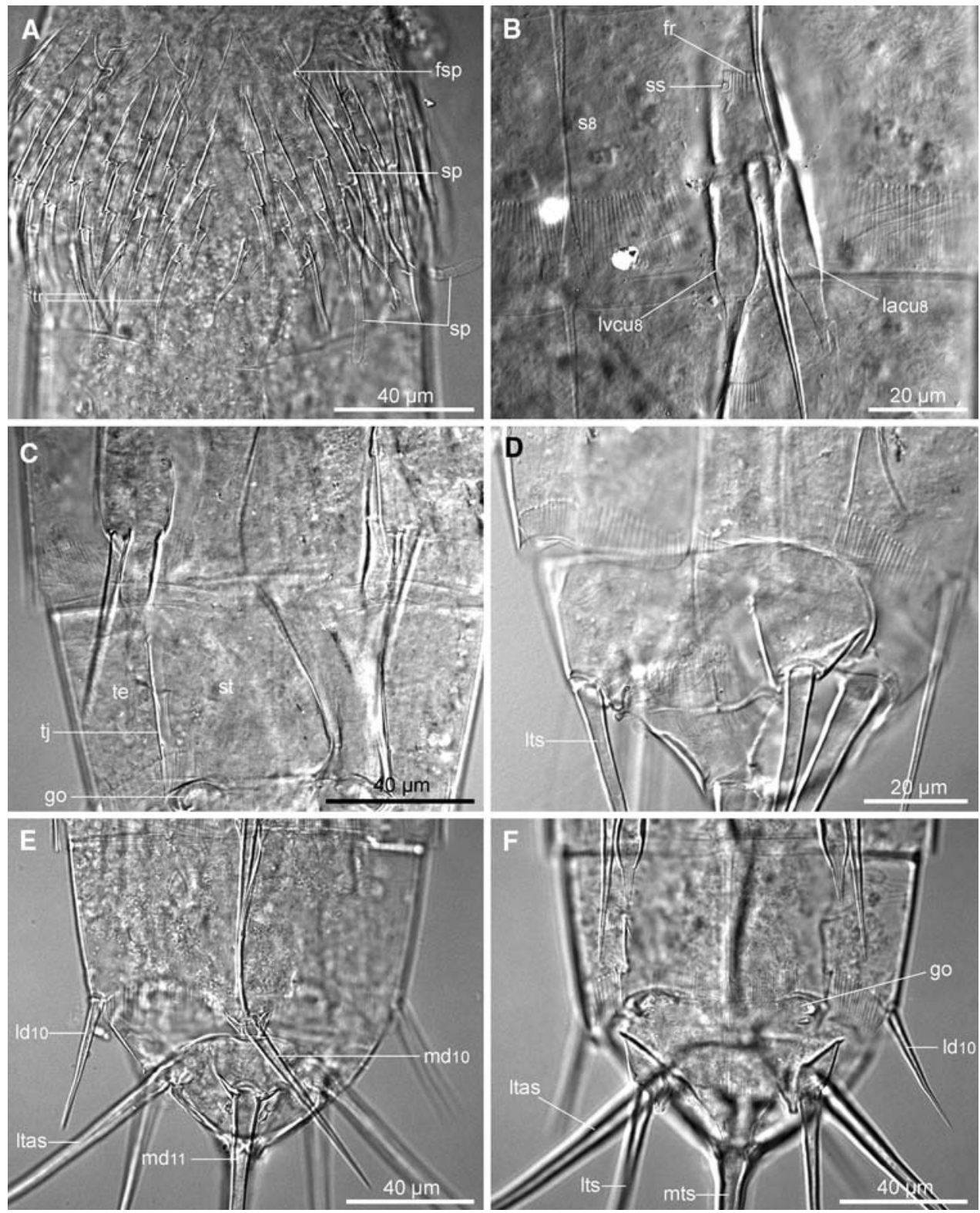

of a pectinate fringe. The ventral part of the posterior margin extends into a thin but broad, caudally extending flap (Fig. 10b). The posterior margins of the following nine segments resemble segment 1 on the dorsal and lateral parts. The ventral parts of the margins have deep notches where spines emerge, and a broad caudal flap extends from each sternal plate (Fig. 10a). Thin fringes may occur on some segment margins, but they appear more like slits rather than actual pectinate fringes.

Middorsal acicular spines are present on segments 1-11, in a notch near each segment's posterior edge. The middorsal spines appear flexible and are densely covered with hairs. Cuspidate spines are present in a lateroventral position on segments 2, 5, 8 and 9, and in a lateral accessory position on segments 6 and 8 (Figs. 9b, 10a, c). The cuspidate spines consist of a swollen proximal part with a few scattered hairs and a narrow distal part with short scale-like hairs. Acicular spines are present in a lateroventral position on 2-4 and 6-8, in a lateral accessory position on segments 5 and 9 , and in a laterodorsal position on segment 10 (Fig. 10e). The latter pair is located posteriorly on the segment and emerges through a notch in the posterior margin of the segment. The acicular spines on segment 2 are very short and flexible, and covered with minute hairs (Fig. 10c). The terminal segment in both sexes has lateral terminal spines, lateral terminal accessory spines and a midterminal spine (Figs. 9d-f, 10e).

\section{Sensory spots}

Pairs of paradorsal sensory spots are located close to the middorsal spines on segments 1-10. The sensory spots 
Table 3 Measurements of adult Antygomonas incomitata from Taranto Bay, Italy, including number of measured specimens $(n)$ and standard deviation $(\mathrm{SD})$

\begin{tabular}{|c|c|c|c|c|}
\hline Character & $n$ & Range & Mean & SD \\
\hline TL & 12 & $515-613 \mu \mathrm{m}$ & $562 \mu \mathrm{m}$ & $25.06 \mu \mathrm{m}$ \\
\hline MSW-7 & 5 & $70-78 \mu \mathrm{m}$ & $73 \mu \mathrm{m}$ & $3.03 \mu \mathrm{m}$ \\
\hline MSW-7/TL & 5 & $12.1-13.9 \%$ & $12.90 \%$ & 0.75 \\
\hline SW-10 & 6 & $60-72 \mu \mathrm{m}$ & $66 \mu \mathrm{m}$ & $3.88 \mu \mathrm{m}$ \\
\hline SW-10/TL & 6 & $10.8-12.1 \%$ & $11.60 \%$ & 0.56 \\
\hline S1 & 12 & $51-64 \mu \mathrm{m}$ & $56 \mu \mathrm{m}$ & $4.56 \mu \mathrm{m}$ \\
\hline S2 & 12 & $40-49 \mu \mathrm{m}$ & $43 \mu \mathrm{m}$ & $2.66 \mu \mathrm{m}$ \\
\hline S3 & 12 & $38-52 \mu \mathrm{m}$ & $42 \mu \mathrm{m}$ & $3.85 \mu \mathrm{m}$ \\
\hline S4 & 12 & $41-52 \mu \mathrm{m}$ & $46 \mu \mathrm{m}$ & $3.10 \mu \mathrm{m}$ \\
\hline S5 & 12 & $45-53 \mu \mathrm{m}$ & $49 \mu \mathrm{m}$ & $3.34 \mu \mathrm{m}$ \\
\hline S6 & 12 & $50-59 \mu \mathrm{m}$ & $54 \mu \mathrm{m}$ & $2.35 \mu \mathrm{m}$ \\
\hline S7 & 12 & $52-60 \mu \mathrm{m}$ & $56 \mu \mathrm{m}$ & $2.55 \mu \mathrm{m}$ \\
\hline S8 & 12 & $55-68 \mu \mathrm{m}$ & $61 \mu \mathrm{m}$ & $4.04 \mu \mathrm{m}$ \\
\hline S9 & 12 & $59-70 \mu \mathrm{m}$ & $63 \mu \mathrm{m}$ & $3.77 \mu \mathrm{m}$ \\
\hline S10 & 12 & $60-65 \mu \mathrm{m}$ & $62 \mu \mathrm{m}$ & $1.75 \mu \mathrm{m}$ \\
\hline S11 & 12 & $45-64 \mu \mathrm{m}$ & $52 \mu \mathrm{m}$ & $5.64 \mu \mathrm{m}$ \\
\hline MD 1 & 12 & $29-34 \mu \mathrm{m}$ & $32 \mu \mathrm{m}$ & $1.62 \mu \mathrm{m}$ \\
\hline MD 2 & 12 & $33-41 \mu \mathrm{m}$ & $37 \mu \mathrm{m}$ & $2.37 \mu \mathrm{m}$ \\
\hline MD 3 & 11 & $40-46 \mu \mathrm{m}$ & $43 \mu \mathrm{m}$ & $2.00 \mu \mathrm{m}$ \\
\hline MD 4 & 12 & $51-62 \mu \mathrm{m}$ & $55 \mu \mathrm{m}$ & $3.30 \mu \mathrm{m}$ \\
\hline MD 5 & 11 & $51-64 \mu \mathrm{m}$ & $58 \mu \mathrm{m}$ & $3.59 \mu \mathrm{m}$ \\
\hline MD 6 & 12 & $49-73 \mu \mathrm{m}$ & $59 \mu \mathrm{m}$ & $6.77 \mu \mathrm{m}$ \\
\hline MD 7 & 12 & $51-66 \mu \mathrm{m}$ & $60 \mu \mathrm{m}$ & $4.33 \mu \mathrm{m}$ \\
\hline MD 8 & 10 & $56-69 \mu \mathrm{m}$ & $62 \mu \mathrm{m}$ & $3.68 \mu \mathrm{m}$ \\
\hline MD 9 & 11 & $57-68 \mu \mathrm{m}$ & $62 \mu \mathrm{m}$ & $3.18 \mu \mathrm{m}$ \\
\hline MD 10 & 12 & $61-74 \mu \mathrm{m}$ & $67 \mu \mathrm{m}$ & $3.29 \mu \mathrm{m}$ \\
\hline MD 11 & 9 & $191-249 \mu \mathrm{m}$ & $221 \mu \mathrm{m}$ & $18.78 \mu \mathrm{m}$ \\
\hline LV 2 (cu) & 12 & $29-35 \mu \mathrm{m}$ & $32 \mu \mathrm{m}$ & $1.91 \mu \mathrm{m}$ \\
\hline LV 2 (ac) & 10 & $11-13 \mu \mathrm{m}$ & $12 \mu \mathrm{m}$ & $0.95 \mu \mathrm{m}$ \\
\hline LV 3 (ac) & 12 & $27-42 \mu \mathrm{m}$ & $31 \mu \mathrm{m}$ & $3.92 \mu \mathrm{m}$ \\
\hline LV 4 (ac) & 12 & $39-47 \mu \mathrm{m}$ & $44 \mu \mathrm{m}$ & $2.50 \mu \mathrm{m}$ \\
\hline LA 5 (ac) & 12 & $41-52 \mu \mathrm{m}$ & $48 \mu \mathrm{m}$ & $3.43 \mu \mathrm{m}$ \\
\hline LV 5 (cu) & 12 & $32-36 \mu \mathrm{m}$ & $34 \mu \mathrm{m}$ & $1.40 \mu \mathrm{m}$ \\
\hline LA 6 (cu) & 12 & $30-36 \mu \mathrm{m}$ & $32 \mu \mathrm{m}$ & $2.02 \mu \mathrm{m}$ \\
\hline LV 6 (ac) & 12 & $46-64 \mu \mathrm{m}$ & $52 \mu \mathrm{m}$ & $4.64 \mu \mathrm{m}$ \\
\hline LV 7 (ac) & 12 & $48-61 \mu \mathrm{m}$ & $53 \mu \mathrm{m}$ & $3.94 \mu \mathrm{m}$ \\
\hline LA 8 (cu) & 12 & $29-40 \mu \mathrm{m}$ & $35 \mu \mathrm{m}$ & $3.08 \mu \mathrm{m}$ \\
\hline LV 8 (ac) & 12 & $51-61 \mu \mathrm{m}$ & $57 \mu \mathrm{m}$ & $2.93 \mu \mathrm{m}$ \\
\hline LV 8 (cu) & 12 & $29-38 \mu \mathrm{m}$ & $34 \mu \mathrm{m}$ & $2.94 \mu \mathrm{m}$ \\
\hline LA 9 (ac) & 12 & $47-57 \mu \mathrm{m}$ & $52 \mu \mathrm{m}$ & $3.17 \mu \mathrm{m}$ \\
\hline LV 9 (cu) & 12 & $31-38 \mu \mathrm{m}$ & $35 \mu \mathrm{m}$ & $2.25 \mu \mathrm{m}$ \\
\hline SL 10 (ac) & 12 & $44-73 \mu \mathrm{m}$ & $54 \mu \mathrm{m}$ & $9.96 \mu \mathrm{m}$ \\
\hline LTS & 11 & $82-102 \mu \mathrm{m}$ & $92 \mu \mathrm{m}$ & $7.84 \mu \mathrm{m}$ \\
\hline LTAS & 12 & $123-138 \mu \mathrm{m}$ & $128 \mu \mathrm{m}$ & $4.63 \mu \mathrm{m}$ \\
\hline MTS & 8 & $414-491 \mu \mathrm{m}$ & $452 \mu \mathrm{m}$ & $24.09 \mu \mathrm{m}$ \\
\hline
\end{tabular}

$a c$ acicular spine, $c u$ cuspidate spine, $L A$ lateral accessory, $L T A S$ lateral terminal accessory spine, $L T S$ lateral terminal spine, $L V$ lateroventral, $M D$ middorsal, $M S W-7$ maximum sternal width (on segment 7), MTS midterminal spine, $S$ segment lengths, $S L$ sublateral, $S W-10$ standard width (on segment 10), $T L$ trunk length consist of numerous pointed papillae, and have a central pore and a lateral pore that are elevated on the tip of a short tube. The tube with the lateral pore indicates that these sensory spots belong to type 2 (sensu Nebelsick 1992). As a peculiarity, one extra, small, unpaired paradorsal sensory spot was observed in two specimens. In both specimens the extra sensory spot was located on segment 2, on the lefthand side of the middorsal spine (Fig. 11c). Paradorsal sensory spots are present on segment 11 as well, near the bases of the middorsal and midterminal spine, respectively (Fig. 11d). The sensory spots near the middorsal spines are modified sensory spots (or type 3 sensu Nebelsick 1992). Each of them consists of a long pedicle, a crown of pointed papillae, and a terminal tube with a pore that extends beyond the papillae. More posteriorly at the segment, close to the base of the midterminal spine, a double pair of sensory spots is present. The anteriormost pair is two rather small type 1 sensory spots with short papillae and one central pore. The second, more posteriorly located pair, is modified sensory spots consisting of a slender pedicle, a crown of papillae and a central, terminal pore but no tube.

A pair of large, laterodorsal type 2 sensory spots is present on segment 1 . The spots are droplet-shaped with a small central pore, a lateral pore with a cilium coming out, and yet another lateral pore on the tip of a short tube. A similar pair of type 2 sensory spots is present on segment 2 in a midlateral position and on segments 4,7 and 9 in a sublateral position (Fig. 11a). Segment 3 has one pair of sublateral sensory spots as well, but these are conspicuously small (ca. $1 \mu \mathrm{m}$ in diameter) and with a single pore only (Fig. 11b). Additional sensory spots belonging to the dorsal series are located on segment 10 . This segment has a pair of subdorsal and laterodorsal sensory spots, both belonging to type 2 .

A special kind of sensory spots are present on segments 6-9. They are relatively small, consisting of a rounded area of short, densely set papillae and with a long slender, gradually tapering tubule protruding from the center (Fig. 11e). Such sensory spots have not been named or reported previously, and will tentatively be referred to as type 4 sensory spots. The sensory spots are located in a lateroventral position, anteriorly on the segment, under a narrow fringed area (Figs. 9b, 11e) (see further description of fringe in section below).

A pair of ventromedial type 2 sensory spots with three pores is present on segment 1 (Fig. 10b). Similar pairs of sensory spots, however, in a more ventrolateral position are present on segments 3, 4, 6 and 7 (Fig. 11e), and in a lateroventral position on segment 10 . A pair of small type 1 sensory spots was observed on two female specimens on segment 11 in a ventrolateral position slightly behind the gonopores (Fig. 10d). However, these sensory spots were not found consistently on all specimens. The only other pair 
Table 4 Summary of nature and location of sensory spots and spines arranged by series in Antygomonas incomitata from Taranto Bay, Italy

\begin{tabular}{|c|c|c|c|c|c|c|c|c|c|c|}
\hline Position segment & MD & PD & SD & LD & ML & SL & LA & LV & VL & VM \\
\hline 1 & $\mathrm{ac}$ & ss2 & & ss2 & & & & & & ss2 \\
\hline 2 & $\mathrm{ac}$ & ss2 & & & ss2 & & & $\mathrm{cu}, \mathrm{ac}$ & & \\
\hline 3 & $\mathrm{ac}$ & ss 2 & & & & ss 1 & & $\mathrm{ac}$ & ss2 & \\
\hline 4 & $\mathrm{ac}$ & ss2 & & & & ss 2 & & $\mathrm{ac}$ & ss2 & \\
\hline 5 & $\mathrm{ac}$ & ss 2 & & & & & $\mathrm{ac}$ & $\mathrm{cu}$ & & \\
\hline 6 & $\mathrm{ac}$ & ss 2 & & & & & $\mathrm{cu}$ & ac, ss 4 & ss2 & \\
\hline 7 & $\mathrm{ac}$ & ss2 & & & & ss 2 & & ac, ss 4 & ss2 & \\
\hline 8 & $\mathrm{ac}$ & ss 2 & & & & & $\mathrm{cu}$ & $\mathrm{ac}, \mathrm{cu}, \mathrm{ss} 4$ & & \\
\hline 9 & $\mathrm{ac}$ & ss2 & & & & ss 2 & $\mathrm{ac}$ & $\mathrm{cu}, \mathrm{ss} 4$ & & \\
\hline 10 & $\mathrm{ac}$ & ss 2 & ss 2 & ac, ss2 & & & & ss 2 & & \\
\hline 11 & $\mathrm{ac}, \mathrm{mts}$ & $\mathrm{ss} 3, \mathrm{ss} 1, \mathrm{ss} 3$ & & & & & ltas & lts, ss 3 & ss $1(!)$ & \\
\hline
\end{tabular}

$L A$ lateral accessory, $L D$ laterodorsal, $L V$ lateroventral, $M D$ middorsal, $M L$ midlateral, $P D$ paradorsal, $S D$ subdorsal, $S L$ sublateral, $V L$ ventrolateral, $V M$ ventromedial, ! indicates that the character was found in a few specimens only, ac acicular spine, $c u$ cuspidate spine, ltas lateral terminal accessory spine, lts lateral terminal spine, $m t s$ midterminal spine, $s s 1 / 2 / 3 / 4$ sensory spot type 1/2/3/4

Fig. 10 Scanning electron micrographs showing trunk morphology in Antygomonas incomitata. a Segments 6-8, ventral view. b Segment 1 , ventral view. c Segment 2, ventral view. d Right sternal plate of segment 11 in female. e Segments 9-11, lateral view. $f r$ fringe, go gonopore, lacu lateral accessory cuspidate spine, $l d$ laterodorsal spine, ltas lateral terminal accessory spine, lts lateral terminal spine, $l v a c$ lateroventral acicular spine, $l v c u$ lateroventral cuspidate spine, $m d$ middorsal spine, $s p$ spinoscalid, $s s 2-4$ sensory spot (digits after label refer to type of sensory spot)
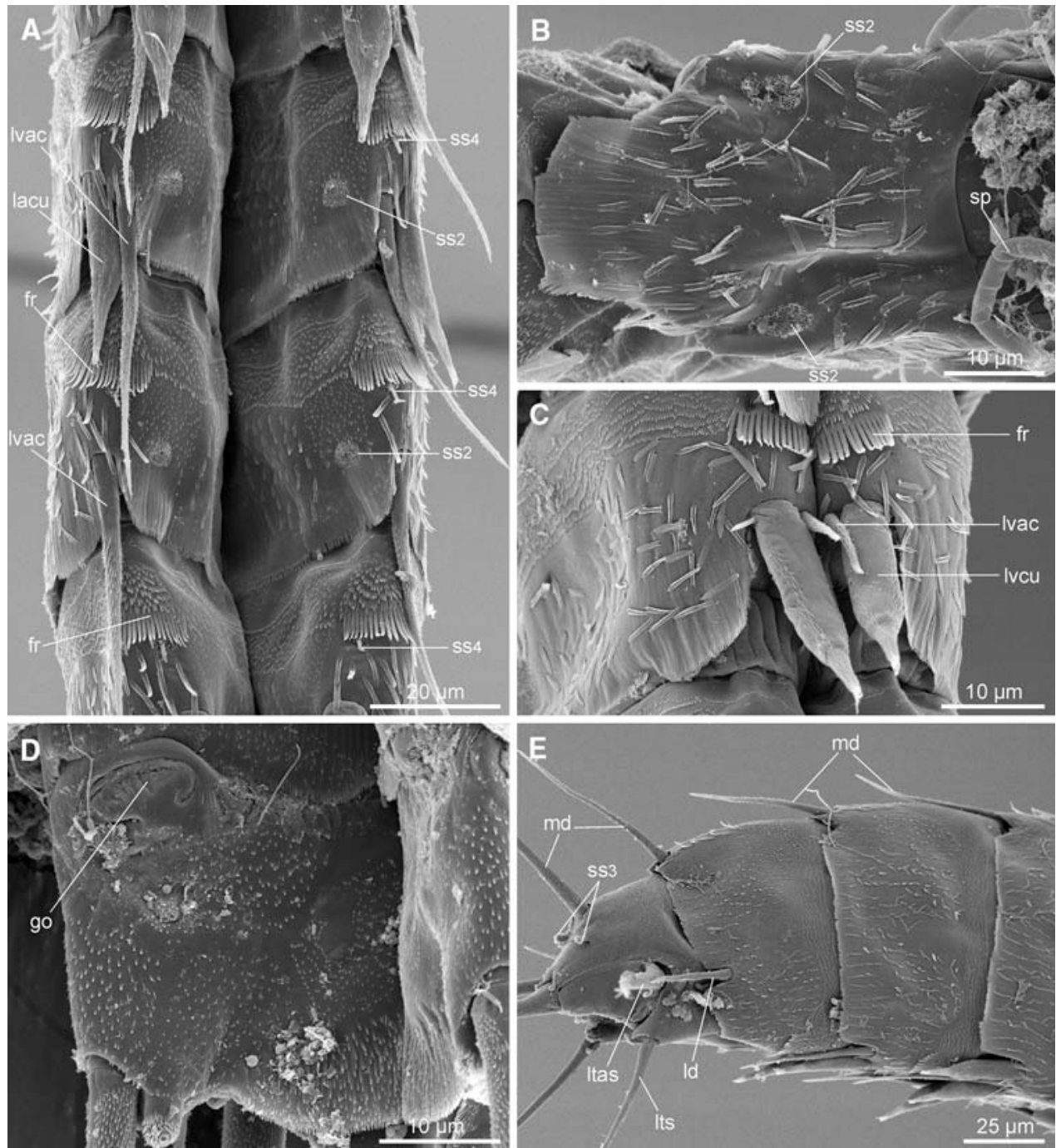
Fig. 11 Scanning electron micrographs showing sensory spots and cuticular details in Antygomonas incomitata. a Sublateral type 2 sensory spot on segment 7. b Very small sublateral type 1 sensory spot on segment 3. c Left paradorsal sensory spot on segment 2 . Note the minute, additional sensory spot next to it, found only on segment 2 in this and one other specimen. d Paradorsal sensory spots on segment 11, laterodorsal view. e Sternal plate of segment 6 showing a large type 2 and a smaller type 4 sensory spot. f Lateroventral modified sensory spots on segment 11 . ch cuticular hair, $f r$ fringe, lts lateral terminal spine, $m d$ middorsal spine, $m t s$ midterminal spine, $p o$ pore, $s s 1-4$ sensory spot (digits after label refer to type of sensory spot), $t u$ tube
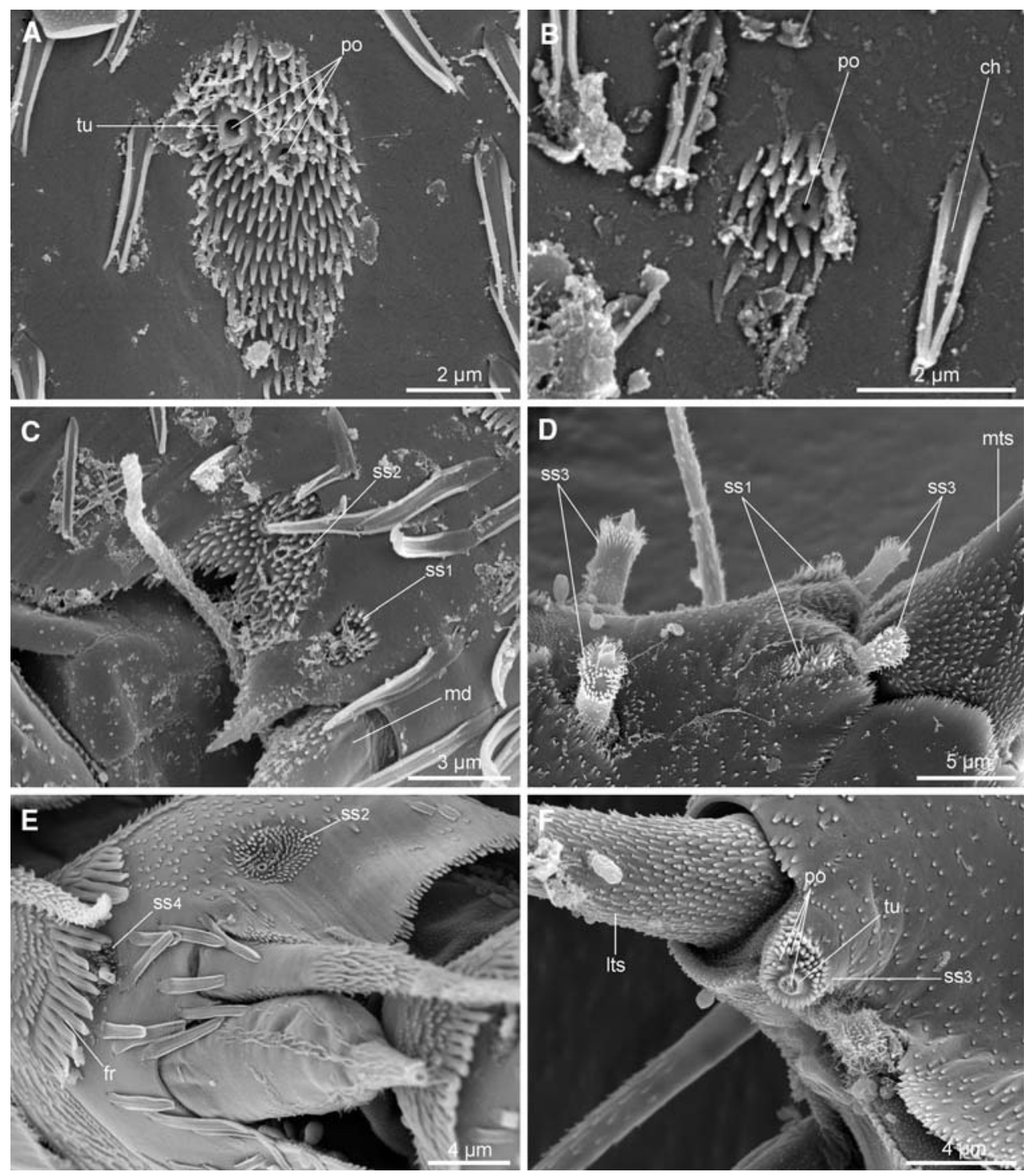

of lateral/ventral sensory spots on segment 11 is one pair of lateroventral modified sensory spots next to the lateral terminal spines (Fig. 11f). These sensory spots consist of a pedicle with terminal papillae, two small pores, and a much larger one on the tip of a short tube.

\section{Glandular cell outlets}

It was not possible to identify any glandular cell outlets, neither with LM nor SEM.

\section{Other cuticular structures}

Segment 1 has scattered cuticular hairs. The hairs are flattened with bent lateral edges, narrow proximal pedicles and truncated tips, which give them a leaf-like appearance (Fig. 10b). On the following ten segments, leaf-like cuticular hairs are scattered over the median and posterior parts of the tergal plates. The anterior parts of the tergal plates of segments 2-10 have no hairs but are ornamented with secondary fringes. Each tergal plate has one narrow anteriormost secondary fringe, followed by a broad, curved fringe. This fringe is followed by four additional closely set, fringes. The cuticular ornamentation of the sternal plates of segments 2-10 follows a distinct pattern. Leaf-like cuticular hairs are present in paired ventromedial patches only. The secondary fringes from the tergal plate continue onto the tergal plates until a ventrolateral position where they stop (Fig. 10a). Near the midsternal junction another secondary fringe form a pair of loops. Posterior to these loops, two elongate patches, probably attachment sites for dorsoventral muscles (see Müller and Schmidt-Rhaesa 2003), are marginally marked with short spikes like those in the secondary fringes. Another patch of spikes is present more lateroventral on the sternal plate. Segment 11 has no leaf-like hairs and is covered with patches of short spikes (Fig. 10d-e). 
Other prominent cuticular structures include short rows of well-developed fringes that are present anteriorly on segments $2-10$. The fringes form combs that, on segments 6-9, partly cover the peculiar tubule bearing type 4 sensory spots (Figs. 9a, b, c, 10e).

It was not possible to locate a sieve plate or any other trace of a protonephridial opening.

Outer primary sexual characters are present in females only, that have a pair of ventrolateral gonopores present in the intersegmental zone between segments 10 and 11 (Figs. 9f, 10d). The gonopores consist of a bent slit with outer thickenings in the cuticle, which almost give them an appearance like a human ear. Other sexual dimorphic characters were not noted.

\section{Comparison with previous observations}

Antygomonas currently comprises three species: A. incomitata Nebelsick 1990, A. oreas Bauer-Nebelsick 1996 and A. paulae Sørensen 2007. A. oreas has only been recorded at a single occasion from a sea mount in the East Pacific (Bauer-Nebelsick 1996), whereas A. paulae has been collected from calcareous sand on Bermuda and along the Atlantic Coast of Florida (Sørensen 2001, 2007). The three species are most easily distinguished by the positions of their cuspidate spines.

Antygomonas incomitata has until now only been recorded at one occasion, and only one specimen was collected by that time. The specimen was collected in the Adriatic Sea south of Rovinj at the Croatian Coast (Nebelsick 1990). Since this single record of the species in 1973, its type locality has been sampled at several occasions, but $A$. incomitata was never found again. Hence, it was surprising to find numerous specimens at the locality in Taranto Bay, South Italy. The morphology of the Italian specimens generally fit the description of the Croatian holotype, except regarding the position of middorsal spines on the posteriormost segments. Contrarily to the Italian specimens, that all have one middorsal spine on each segment, the Croatian holotype has, according to the description, no middorsal spine on segment 10 but has instead two middorsal spines on segment 11. This reported spine pattern would be rather unusual and unique among kinorhynchs, and we consider it more likely that a middorsal spine on segment 10 mistakenly has been observed as if it emerged from the anteriormost part of segment 11 . Since the description was based on a specimen that was mounted on its lateral side, such a mistake could easily have occurred. It was not possible to loan the holotype for reexaminations, but based on the otherwise identical morphology, we consider the Italian specimens as being conspecific with $A$. incomitata.

\section{Arrangement of head appendages}

The exact arrangement of introvert and mouth cone appendages could not be observed in the holotype of $A$. incomitata, but detailed descriptions are provided for its two close relatives, A. oreas and A. paulae (see BauerNebelsick 1996; Sørensen 2007). Whereas the arrangements are identical for $A$. incomitata and $A$. oreas, only the ring-wise arrangement differs slightly in A. paulae, which has two scalids in ring 03 in even numbered sections (Sørensen 2007), opposed to two scalids in ring 04 in A. incomitata (Fig. 8) and A. oreas (see Bauer-Nebelsick 1996). Also the morphology of oral styles and scalids appears to be very homogenous within the genus. This also includes the conspicuous segmented tips of the spinoscalids.

As stated above, species of Antygomonas share their section-wise scalid arrangement with a diverse range of other kinorhynch species, whereas the morphology of the scalids shows most similarity with those found in species of Semnoderes.

\section{Trunk morphology and spine pattern}

The trunk segments in A. incomitata were originally described as consisting of a closed ring in segment 1 , followed by ten segments that each consisted of a bent tergal plate with a midventral articulation (Nebelsick 1990). Later, with the description of $A$. oreas, it was noted that the terminal segment in A. oreas and A. incomitata actually consisted of one tergal and two sternal plates (Bauer-Nebelsick 1996). More recently Sørensen (2007) reported the presence of indistinct tergosternal junctions in A. paulae and re-examined type material of $A$. oreas, indicating that all segments from 2 to 11 consist of a tergal and two sternal plates. With the present examination, this body plan is confirmed for A. incomitata as well, which means that a trunk with the first segment consisting of a closed ring and the following 10 segments of one tergal and two sternal plates can be considered a common trait for all known species of Antygomonas. As a consequence, species of Antygomonas go from having a segment architecture that would be unique among kinorhynchs to possessing an architecture that is shared with several other genera, including Tubulideres, Semnoderes, Campyloderes, Centroderes, Condyloderes, Dracoderes, Polacanthoderes, Fissuroderes, and the homalorhagid genus Neocentrophyes.

As it is already discussed above, under $S$. armiger, species of Antygomonas share several features with this species, inclusive indented anterior margins of the first segment and the spine composition of segment 2 . The additional similarities in trunk segment architecture, and 
introvert appendage morphology and arrangement could potentially bring the two genera even closer together.

\section{Sensory spots}

The distribution of sensory spots in the Italian population of A. incomitata fits the reported pattern from the Croatian holotype on the first five segments. The peculiar, lateroventral type 4 sensory spots on segments 6-9 are not mentioned in the original description, but since these spots are situated under the lateroventral fringes, they are extremely difficult to observe in LM-probably impossible in a laterally mounted specimen. Also the sublateral sensory spots on segments 7 and 9, and the sub- and laterodorsal ones on segment 10 are not mentioned in the description. It remains uncertain whether they have been missed or if this is due to geographical variation. A lateroventral sensory spot on segment 10 is reported to occur in the left side only in the Croatian holotype, whereas such sensory spots were present in both sides in the Italian population.

Comparison with A. paulae and A. oreas shows that all three species have paradorsal sensory spots on segments 19, whereas only A. paulae and A. incomitata have paradorsal sensory spots on segment 10 . All three species have paradorsal modified sensory spots on segment 11 .

The distribution of sensory spots in the lateral series on segment 1 is identical in the three species. A. paulae also has type 2 sensory spots with three pores in the laterodorsal and ventrolateral positions (Sørensen 2007), whereas $A$. oreas is described as having sensory spots with "two or three pores" (Bauer-Nebelsick 1996). From segments 2-8, $A$. oreas has no sensory spots in the lateral series, which differs from A. paulae and A. incomitata that share the presence of midlateral sensory spots on segment 2 , and sublateral/lateral accessory sensory spots on segments 4 and 7 . Both A. paulae and A. oreas display a pair of dorsolateral sensory spots on segment 9 . In A. incomitata these sensory spots appear in more sublateral position. The positions of sensory spots on segment 10 are identical for A. paulae and A. incomitata, whereas $A$. oreas has no sensory spots at all on this segment.

The lateroventral type 4 sensory spots are reported neither from A. paulae nor A. oreas. The observation of these special, and partly hidden, sensory spots in A. incomitata prompted a reexamination of $A$. paulae and these examinations confirmed that such sensory spots are not present in this species.

The distribution of ventral sensory spots on segments 17 is identical for A. paulae and A. incomitata, whereas $A$. oreas lacks ventrolateral sensory spots on segments 3,4 and 7. However, A. paulae and A. oreas share the presence of ventrolateral sensory spots on segment 8 . Such sensory spots are absent in A. incomitata. In general A. paulae and
A. incomitata appear to show most similarity in distribution of sensory spots, whereas A. oreas are poorer in sensory spots.

A noteworthy feature in species of Antygomonas is the presence of type 2 sensory spots, viz. sensory spots consisting of numerous cuticular papillae, one or two regular pores and one pore elevated on the tip of a small tube (see Nebelsick 1992). The presence of type 2 sensory spots was first considered being restricted to homalorhagid species (Nebelsick 1992), but recently Sørensen (2007) demonstrated their presence in the cyclorhagid species A. paulae. This kind of sensory spots is apparently the most common in A. incomitata as well. Interestingly, the presence of type 2 sensory spots has now been demonstrated for species of another cyclorhagid species, namely $S$. armiger, that shows a pair of ventromedial type 2 sensory spots on segment 1 (Fig. 5d). This feature adds to the list of similarities shared between species of Antygomonas and Semnoderes, and their phylogenetic significance should be tested in a numerical cladistic analysis.

\section{Excretory system and sieve plate}

The excretory system in all kinorhynchs are supposed to consist of a pair of protonephridia, located in segment 8 , that through canal cells connects to a pair of nephridiopores that open in a dorsolateral to sublateral position on segment 9 (Kristensen and Hay-Schmidt 1989; Kristensen and Higgins 1991; Neuhaus and Higgins 2002). This architecture has been considered common for all kinorhynchs. Whereas a detailed study of the protonephridial system requires examinations with TEM, the nephridiopores form distinct cuticular pored fields, so-called sieve plates, that are easily observed with LM or SEM. Such sieve plates have been reported from many species, e.g., Pycnophyes greenlandicus (see Kristensen and Higgins 1991), Fissuroderes rangi (see Neuhaus and Blasche 2006); Cephalorhyncha liticola (see Sørensen 2008), Echinoderes teretis (see Brown 1985), E. aquilonius (see Kristensen and Hay-Schmidt 1989), E. coulli (see Kristensen and Higgins 1991), E. cantabricus and E. hispanicus (see Pardos et al. 1998), E. spinifurca (see Sørensen et al. 2005). Paired sieve plates have furthermore been observed in species of Centroderes (Sørensen, personal observation). However, even though sieve plates are present in a broad range of taxa, and have been considered a basal trait for kinorhynchs, the absence of differentiated sieve plates can be confirmed for $A$. incomitata, as well as the other species examined in the present contribution. Also previous studies can positively confirm the absence of such structures in certain species, including A. paulae (see Sørensen 2007), Tubulideres seminoli and Zelinkaderes seminoli (see Sørensen et al. 2007), and Polacanthoderes martinezi (see Sørensen 2008). 
Hence, the presence of differentiated sieve plates may be less universal than previously thought, and the presence or absence of such structures should be examined more carefully in future contributions in order to understand the systematic significance of this character.

\section{Conclusions}

Combined SEM and LM observations revealed new information about the detailed morphology in the two species included in the present study. S. armiger represents a genus from which no species previously has been examined with SEM. Information about the morphology and arrangement of introvert appendages was missing, or was at least very fragmentary. Thorough examinations revealed information about scalid morphology and patterns, and showed, contrarily to previous reports, that trichoscalids are present. SEM examinations also clearly demonstrated that segment 1 consists of a closed ring with deep middorsal and midventral incisions, and not two lateral plates as preciously suggested. Furthermore, the detailed mapping of the species sensory spot distribution was provided, and it was shown that sensory spots of type 1,2 and 3 were present on the species. Finally, the presence of papillae, that otherwise have been observed in species of cf. C. macquariae only, was demonstrated in female specimens.

Antygomonas incomitata belong to a genus with two other species that have been described in detailed. However, information about $A$. incomitata has been scarcer, as only one single specimen has been studied until now. Based on SEM examinations of new material, we could provide a detailed description of the morphology and arrangement of appendages in the mouth cone and introvert, which make Antygomonas the only polytypic kinorhynch genus where such information is available from all known species. Comparison with previous contributions shows that the morphology and arrangement of scalids are very homogenous within the genus. SEM examinations of cuticular structures on the trunk segments revealed the presence of a kind of sensory spots that has not been observed previously. The sensory spots consist of an area with densely set papillae, with a long slender, gradually tapering tubule protruding from the center. Such observations stress the importance of detailed SEM studies, in order to obtain a more completely idea about the disparity of morphological structures within kinorhynchs.

During the study, several striking similarities between species of Semnoderes and Antygomonas were noted. These shared features include: Similar morphology of spinoscalids, identical or almost identical distribution of scalids, anterior margins of segment 1 with more or less developed incisions, special and identical spine composition in segment 1 , and presence of ventromedial type 2 sensory spots on segment 1 . The observed similarities could indicate a closer relationship between species of these genera, and their phylogenetic significance should be tested in a formal cladistic analysis.

Acknowledgments We thank Dr. Maria Gallo D'Addabbo who faciliated the campaign in Italy, and Gianluca Accocli who helped sorting the Italian samples. We are furthermore indepted to Dr. Fernando Pardos for providing the line art illustration of S. armiger (Fig. 3), and to two anonymous referees for improving the manuscript with good suggestions. Funding was provided by the Danish Natural Science Research Council (Grant No. 21-04-0331). The compound microscope, camera lucida and imaging software were funded by the Carlsberg Foundation (Grant No. 2005-1-545) and the Novo Nordisk Foundation.

\section{References}

Adrianov AV, Malakhov VV (1999) Cephalorhyncha of the world ocean. KMK Scientific Press, Moscow

Adrianov AV, Murakami C, Shirayama Y (2002) Taxonomic study of the Kinorhyncha in Japan II. Condyloderes setoensis, a new species (Kinorhyncha: Cyclorhagida) from Tanabe Bay (Honshu Island)-first representative of the genus in the Pacific Ocean. Proc Biol Soc Wash 115:189-216

Aguinaldo AMA, Turbeville JM, Lindford LS, Rivera MC, Garey JR, Raff RA, Lake JA (1997) Evidence for a clade of nematodes, arthropods and other moulting animals. Nature 387:489-493

Băcescu M (1968) Class Kinorhyncha. Determination of fauna from the Black Sea and Azov Sea. Naukova Dumka 1:237-250

Băcescu M, Băcescu E (1956) Kinorhinchii-Reprezentati ai unei clase de animale, nouă pentru fauna Rominească. Comunicările Academiei RPR 6:543-549

Bauer-Nebelsick M (1995) Zelinkaderes klepali sp.n., from shallow water sands of the Red Sea. Ann Naturh Mus Wien 97B:57-74

Bauer-Nebelsick M (1996) Antygomonas oreas sp.n., a new deep sea kinorhynch from the Pacific Ocean. Ann Naturh Mus Wien 98B:5-22

Brown R (1985) Developmental and taxonomic studies of Sydney Harbour Kinorhyncha. Ph.D. thesis. Macquarie University, Australia, pp 193 + figures and plates

Brown R (1989) Morphology and ultrastructure of the sensory appendages of a kinorhynch introvert. Zool Scr 18:471-482

Dunn CW, Hejnol A, Matus DQ, Pang K, Browne WE, Smith SA, Seaver E, Rouse GW, Obst M, Edgecombe GD, Sørensen MV, Haddock SHD, Schmidt-Rhaesa A, Okuso A, Kristensen RM, Wheeler WC, Martindale MQ, Giribet G (2008) Broad phylogenomic sampling improves resolution of the animal tree of life. Nature 452:745-749

$\mathrm{G}^{\mathrm{a} O r d o ́ n ̃ e z ~ D, ~ P a r d o s ~ F, ~ B e n i t o ~ J ~(2000) ~ C u t i c u l a r ~ s t r u c t u r e s ~ a n d ~ e p i-~}$ dermal glands of Echinoderes cantabricus and E. hispanicus (Kinorhyncha, Cyclorhagida) with special reference to their taxonomic value. J Morphol 246:161-178

Gardóñez D, Pardos F, Benito J (2008) Three new Echinoderes (Kinorhyncha, Cyclorhagida) from North Spain, with new evolutionary aspects of the genus. Zool Anz 247:95-111

Higgins RP (1967) The Kinorhyncha of New-Caledonia. Expedition Française sur Recifs Coralliens de la Nouvelle Caledonia 2:75-90

Higgins RP (1969) Indian Ocean Kinorhyncha: 1, Condyloderes and Sphenoderes, new cyclorhagid genera. Smithsonian Contrib Zool 14:1-13

Higgins RP (1988) Kinorhyncha. In: Higgins RP, Thiel H (eds) Introduction to the study of Meiofauna. Smithsonian Institution Press, Washington, pp 126-133 
Higgins RP (1990) Zelinkaderidae, a new family of cyclorhagid Kinorhyncha. Smithsonian Contrib Zool 500:1-26

Kristensen RM, Hay-Schmidt A (1989) The protonephridia of the Arctic kinorhynch Echinoderes aquilonius (Cyclorhagida, Echinoderidae). Acta Zool 70:13-27

Kristensen RM, Higgins RP (1984) Revision of Styraconyx (Tardigrada: Halechiniscidae), with description of two new species from Disko Bay, West Greenland. Smithsonian Contrib Zool 391:1-40

Kristensen RM, Higgins RP (1991) Kinorhyncha. In: Harrison FW, Ruppert EE (eds) Microscopic anatomy of invertebrates, the Aschelminthes, vol 4. Wiley, New York, pp 377-404

McIntyre AD (1962) The class Kinorhyncha (Echinoderida) in British waters. J Mar Biol Assoc UK 42:503-509

Müller MCM, Schmidt-Rhaesa A (2003) Reconstruction of the muscle system in Antygomonas sp. (Kinorhyncha, Cyclorhagida) by means of phalloidin labeling and cLSM. J Morphol 256:103-110

Nebelsick M (1990) Antygomonas incomitata gen. et sp. n. (Cyclorhagida, Kinorhyncha) and its phylogenetic relationships. Zool Scr 19:143-152

Nebelsick M (1992) Sensory spots of Echinoderes capitatus (Zelinka, 1928) (Kinorhyncha, Cyclorhagida). Acta Zool 73:185-195

Nebelsick M (1993) Introvert, mouth cone, and nervous system of Echinoderes capitatus (Kinorhyncha, Cyclorhagida) and implications for the phylogenetic relationships of Kinorhyncha. Zoomorphology 113:211-232

Neuhaus B (1993) Postembryonic development of Paracentrophyes praedictus (Homalorhagida): neoteny questionable among the Kinorhyncha. Zool Scr 24:179-192

Neuhaus B (2004) Description of Campyloderes cf. vanhoeffeni (Kinorhyncha, Cyclorhagida) from the Central American East Pacific Deep Sea with a review of the genus. Meiofauna Marina 13:3-20

Neuhaus B, Blasche T (2006) Fissuroderes, a new genus of Kinorhyncha (Cyclorhagida) from the deep sea and continental shelf of New Zealand and from the continental shelf of Costa Rica. Zool Anz 245:19-52

Neuhaus B, Higgins RP (2002) Ultrastructure, biology and phylogenetic relationships of Kinorhyncha. Integr Comp Biol 42:619-632

Nyholm K-G (1947) Studies in the Echinoderida. Ark Zool 39A(14): $1-36$
Pardos F, Higgins RP, Benito J (1998) Two new Echinoderes (Kinorhyncha, Cyclorhagida) including a reevaluation of kinorhynch taxonomic characters. Zool Anz 237:195-208

Sheremetevskij AM (1974) Kinorhynchs of the Black Sea. Zool Zhurnal 53:974-987

Sørensen MV (2001) On the rotifer fauna of Bermuda, including notes on the associated meiofauna and the description of a new species of Encentrum (Rotifera: Ploima: Dicranophoridae). Proc Biol Soc Wash 114:725-736

Sørensen MV (2006) New kinorhynchs from Panama, with a discussion of some phylogenetically significant cuticular structures. Meiofauna Marina 15:51-77

Sørensen MV (2007) A new species of Antygomonas (Kinorhyncha: Cyclorhagida) from the Atlantic coast of Florida, USA. Cah Biol Mar 48:155-168

Sørensen MV (2008) A new kinorhynch genus from the Antarctic deep-sea and a new species of Cephalorhyncha from Hawaii (Kinorhyncha: Cyclorhagida: Echinoderidae). Org Divers Evol 8:230-232 (electronic supplementary: 230e1-230e18)

Sørensen MV, Pardos F (2008) Kinorhynch systematics and biologyan introduction to the study of kinorhynchs, inclusive identification keys to the genera. Meiofauna Marina 16:21-73

Sørensen MV, Heiner I, Ziemer O (2005) A new species of Echinoderes from Florida (Kinorhyncha: Cyclorhagida). Proc Biol Soc Wash 118:499-508

Sørensen MV, Heiner I, Ziemer O, Neuhaus B (2007) Tubulideres seminoli gen. et sp. nov. and Zelinkaderes brightae sp. nov. (Kinorhyncha, Cyclorhagida) from Florida. Helgoland Mar Res 61:247-265

Sørensen MV, Hebsgaard MB, Heiner I, Glenner H, Willerslev E, Kristensen RM (2008) New data from an enigmatic phylum: evidence from molecular sequence data supports a sister group relationship between Loricifera and Nematomorpha. J Zoolog Syst Evol Res 46:231-239

Zelinka C (1928) Monographie der Echinodera. Verlag Wilhelm Engelmann, Leipzig

Ziemer O (2001) Die Morphologie der Pycnophyes (Kinorhyncha, Homalorhagida) von vier Standorten in Grönland unter besonderer Berücksichtigung des Introverts. Master thesis, University of Hamburg, Germany 